\title{
(2) \\ Sacred Connections with Cat-tail (Typha, Typhaceae) - Dragons, water-serpents and reed-maces
}

\author{
Daniel F. Austin
}

\section{Research}

\begin{abstract}
Names are only one factor linking cat-tails to humans for over 3000 years. The generic name Typha was derived from Greek typhe that is linguistically related to Typhon, typhoon, and typhus. These words link four concepts monsters, storms, diseases, and plants. A tangled history of the words and ideas linking them began with the ancestors of the Indo-Europeans perhaps before $1800 \mathrm{BCE}$. Either those views spread from the Old World into the New with successive waves of immigrants or there is a remarkable convergence. Confusion and other factors leading to misunderstanding and simpler translations are outlined.

Los nombres son solamente uno de los factores que relacionan los tules a los humanos por más de 3000 años. El nombre genérico Typha fue derivado del Griego typhe el cual esta relacionado linguísticamente a Typhon, tifon y tifus. Estas palabras relacionan cuatro conceptos - monstruos, tormentas, enfermedades y plantas. Una historia compleja de estas palabras y de las ideas que las relacionan comenzo con los ancestros de los Indo-Europeos quiza antes de 1800 AC. Esas ideas se propagaron desde el Viejo Mundo hacia el Nuevo Mundo a través de sucesivas oleadas de emigrantes o resultan de una convergencia extraordinaria. Se delinean varios factores y confusiónes que han llevado a traducciónes simplificadas y conceptos erróneos.
\end{abstract}

\section{Introduction}

"Of tzité [Erythrina] the flesh of man was made, but when woman was fashioned by the Creator and the Maker, her flesh was made of reeds [puj, Typha]." Part I, Chapter 3, Popul Vuh (Goetz \& Morley 1954)

Cat-tails are used by people around the world as a source of food and household items, and hundreds of publica- tions discuss this (e.g., Morton 1975, Saha 1968, Thieret \& Luken 1996, Turner 1998). What has barely been suggested in the literature is that Typha also functioned as a significant symbolic link to deities. That aspect of the utilitarian cat-tails is critical to understanding its importance to humans. This discussion will not update accounts of uses but investigates the genus from a novel perspective - it explores common names and religions to show that Typha provides more than just edible and domestic materials.

Peré Jacques Marquette and Louis Joliet recorded a dragon image in 1673 of what indigenous Iliniwek called a Piasa on a cliff near what is now Alton, Illinois (Henson 1957). The Piasa was my introduction to the connection between the American pantheon and cat-tails in the 1960s, but I did not know that until about 40 years later. When I discovered that the Omaha considered the cat-tail sacred (Austin 2004), and that the Hopi used Typha during their Niman Kachina, it was clear that I was missing something. Then, when disagreement was found about the etymological derivation of the genus Typha, I realized

\section{Correspondence}

Daniel F. Austin, Arizona-Sonora Desert Museum, 2021 N. Kinney Road, Tucson, AZ 85743, U.S.A.

daustin@desertmuseum.org

Ethnobotany Research \& Applications 5:273-303 (2007) 
there might be a connection between dragons, water-serpents, and cat-tails.

\section{Methods}

Library searches were employed to seek multi-cultural views and uses of Typha. Specifically, literature was searched for common names applied to Typha and any non-secular purposes for the plants. Names were translated where possible. Utilizations in a religious context were evaluated for similarities and differences. Based on the way Hopi and Omaha regarded Typha, the hypothesis was that some people consider the plants holy.

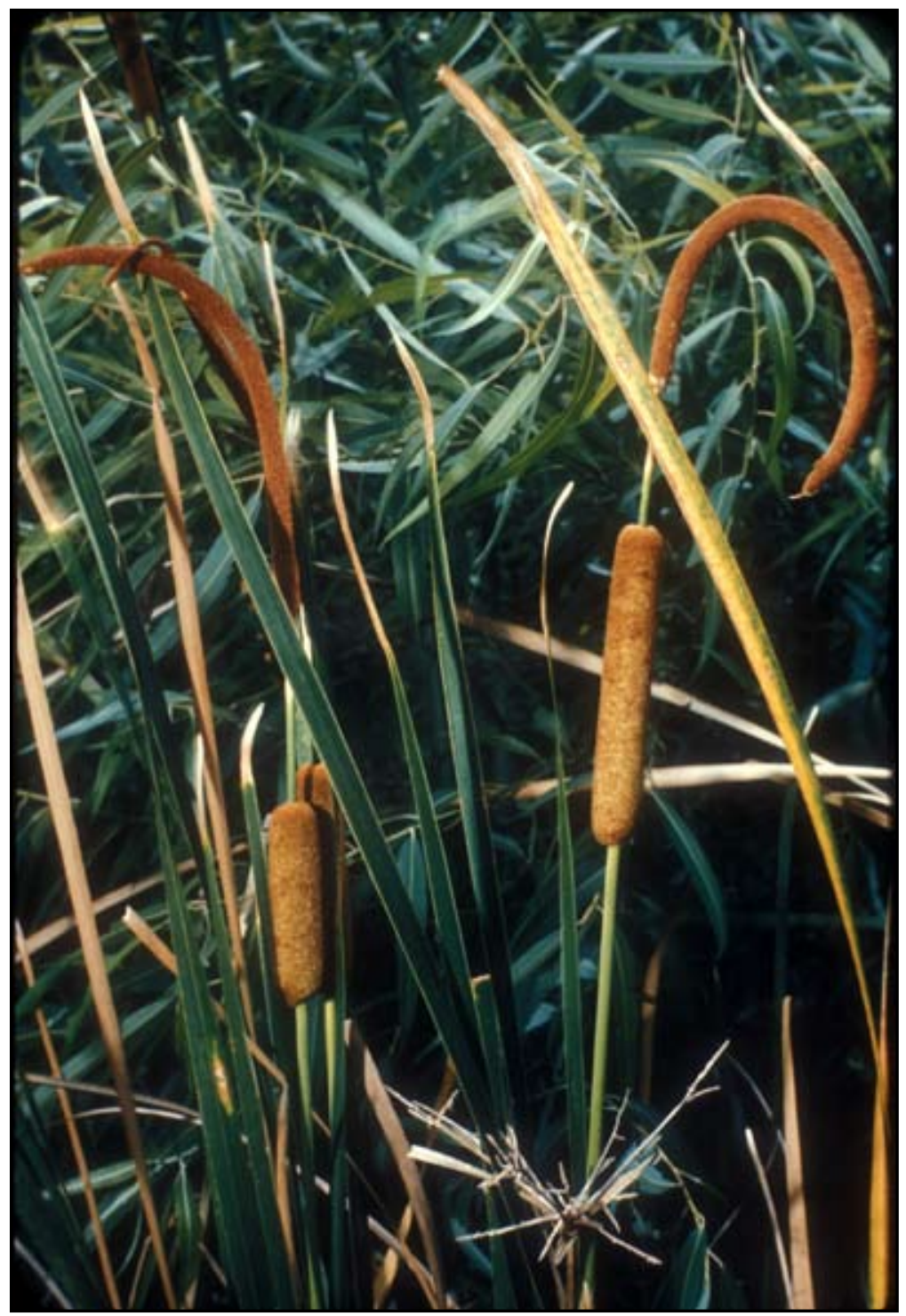

Figure 1. Typha domingensis Pers. with fruits and leaves. Everglades near West Palm Beach, Florida.
Four questions are explored: Do common names show diversity? Do any names point to cat-tails (Typha) being respected? Why are cat-tails revered? Is there a link between Typha, wetlands, and dragons?

\section{Results}

\section{Common Names}

People everywhere have names for these plants in their own languages, some surely as old as their uses. While no attempt has been made to sample all of the languages in which Typha has names, or to include a broad spectrum of those just in English, the Appendix gives 153 Old World and 141 New World names. These belong to 63 language families and subfamilies (Gordon 2005).

Some names are simple and others are complex. Simple names typically indicate great time depth of usage. Those that are translatable, while often more recent, sometimes yield additional information about people's views of the plants. That cattails have simple names (monomorphemic, unanalyzable root) in languages as different as Arabic, Greek, Maori, Russian, Sanskrit, Spanish, Japanese, and others indicates that the plants have been part of people's lives for thousands of years. Similarly, in the New World Typha has simple names in languages as old as Mayan (1200-600 BCE) (Cavalli-Sforza et al. 1994), and those as recently diverged as Apachean Diné (1300-1400 CE) (Hoijer 1956, Ruhlen 1998). Tepiman languages are 1000-50 BCE (Shaul \& Hill 1998), and thus intermediate between Mayan and southwestern Diné. Names show also that Typha has been involved in not only secular life (e.g., Morton 1975), but played prominent roles in people's sacred lives.

The number of names within each language family varies in part because they may be applied to several Typha species. When more than one grows in a region each may be given a distinct variant of the name. This naming of species is complicated because of differing taxonomic philosophies.

Some common names have been used for more than one genus of plants. One example illustrates the problem, especially since it is the most extreme. The word "tule" was derived from Náhuatl tollin, which has long meant Typha to people in Mexico. Since 


\section{Austin - Sacred Connections with Cat-tail (Typha, Typhaceae) - Dragons, water-serpents and reed-maces}

about 1837, "tule" was applied to the sedge Schoenoplectus (formerly Scirpus; Cyperaceae), particularly in California, but also elsewhere (Bourke 1892). Since the word "tule" was loaned from central Mexico to California, the application changed. The other instance is likely confusion because Bourke saw the Apache gathering pollen from stands of cat-tail, but the sedge is often present also (Long et al. 2003). At least the Chiricahua and Mescalero Apache did use the sedge pollen at times but it was often mixed with cat-tail (Castetter \& Opler 1936). This discussion ignores references to the sedge.

\section{Old World Connections}

Although it is a contorted, complicated history only summarized here, the old proto-Indo-European gods of storms

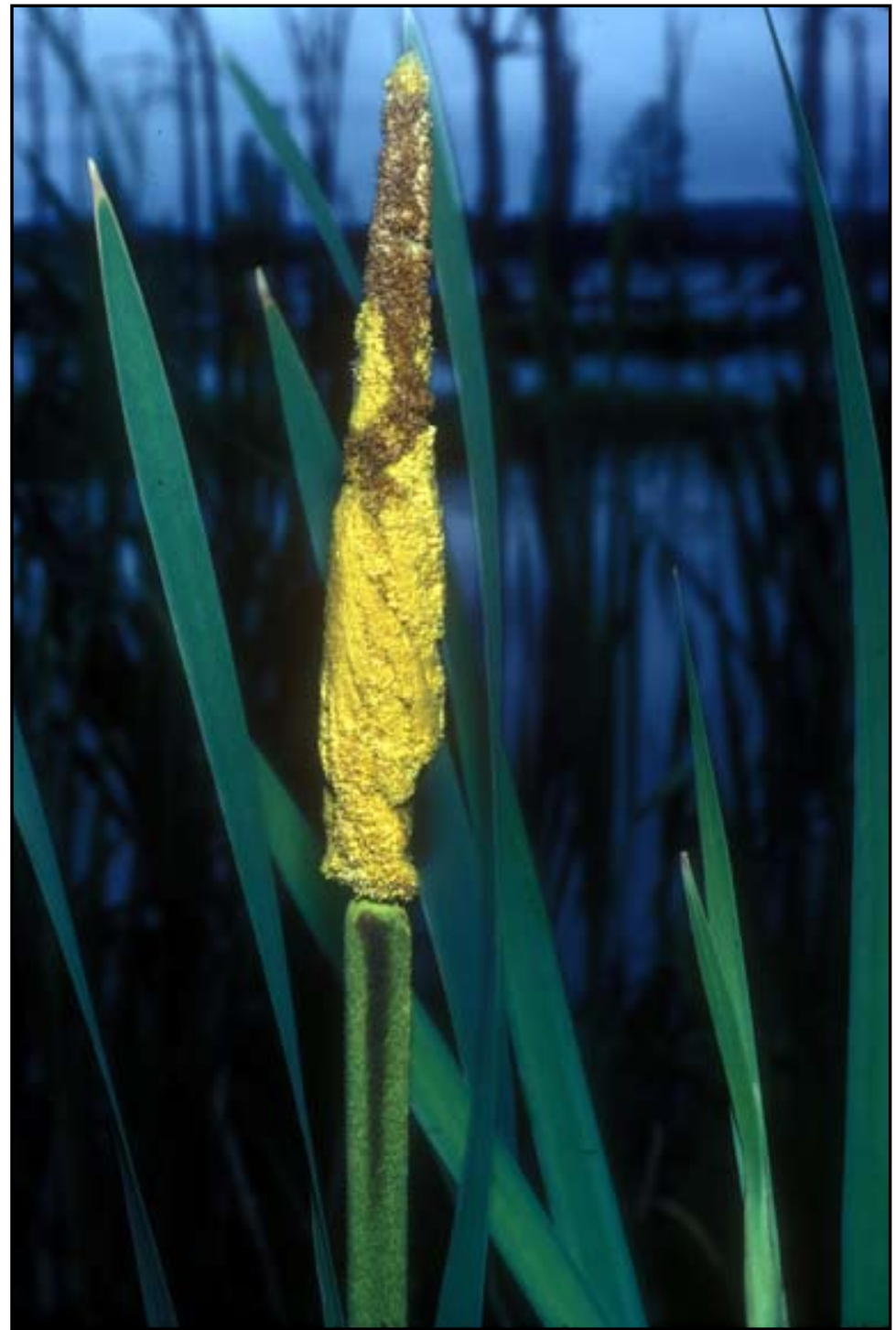

Figure 2. Typha latifolia L. with male inflorescence (above) touching female (below). Mt. Vernon, Illinois. and volcanoes, gave rise to a name subsequently applied to plants, storms, and a disease. The connection that these deities, storms, and disease have with cat-tails is an allusion to smoke. That association developed before 3000 years ago.

Cat-tails belong to the genus Typha, a name that has been written for these plants since Theophrastus (372287 BCE) called them tiphe (тU่ $\varphi \eta$ ) and Dioscorides (fl. AD 40-80) wrote tiphes (TU period, most scholars retained the modern Latin spelling (Linnaeus 1753). While the early Europeans knew only two, now 8-13 species are recognized (Smith et al. 2004). The genus is worldwide in wetlands, and people everywhere have recognized it for millennia.

The Latin Typha is cognate with Greek typhe, as many have pointed out (cf. Nicolson in Smith 1993 for spelling on borrowing from Greek to Latin). Morton (1975) said simply that the generic name was taken from Greek "typhos, marshes." Others, including Thieret \& Luken (1996) and Mitich (2000), concluded that Typha was from the Greek typhein, to smoke. Mitich (2000) thought that the plants were originally named because the seeds being shed from the spikes resembled smoke or a cloud. Thieret \& Luken (1996) believed the reference was more likely because Typha was used "...for maintaining smoky fires or to the smoky-brown color of the fruiting spikes." Moreover, Thieret \& Luken (1996) specifically excluded derivation from Greek typhos. Ward (2007) sided with Morton (1975) in favor of "marsh." The story of the generic name is intimately involved with Greek words for several natural and religious entities, and these authors have oversimplified its derivation.

Many westerners are introduced to the cat-tail by the Bible. While cat-tail is mentioned several times, probably the most famous occurrence in the Old Testament (Exodus 12:15) is to Moses being found in the bulrushes. Suf oIn is the Hebrew word used for Typha in that sentence. Zohary (1982) argued that the Hebrew suf is cognate with Typha, and that the edible Ethiopian grass seed tef (Eragrostis tef (Zucc.) Trotter) is cognate with both.

What has been omitted is that Typha and typhe are cognate with Greek words typhaon, typhoeus, typhōn, and typhos. All of these words are declensions of typhein, date back millennia, and are taken from Greek stories usually called myths. 


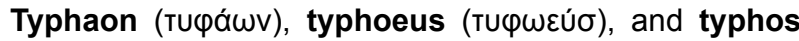

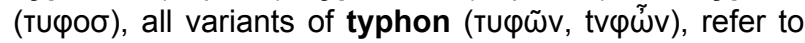
a giant monster (Atsma 2007, Encyclopedia Brittanica 2006, OED 2006, Wikipedia 2007). The Greek Typhon is cognate with the Indo-European root dheub- or dheubh, and Old English dop (deep) from Germanic *deupaz. By Indo-European times, the root word already referred to "bottom," "foundation," "depths," and the monsters believed to inhabited them (American Heritage 2000, Pokorny 1959).

Hesiod narrated Typhon's birth: "But when Zeus had driven the Titans from heaven, huge Earth [Gaia, Гaĩa] bore her youngest child Typhoeus of the love of Tartarus [Tápтapos, deep place], by the aid of golden Aphrodite" (from Theogony). Typhon was a serpent-like dragon (Murison 1905) having a hundred heads, each breathing out flames. He was also a creator of springs, and is associated with water, including bringing rain (Frazer 1890). Among his children with Echidna (ekhis, "she viper;" the

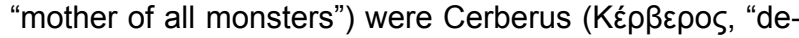
mon of the pit"), the Lernaean hydra, and the Chimaera (Xínaıpa, a fire-breathing female monster with a lion's head, a goat's body, and a serpent's tail). Typhon was mentioned by Homer's ("O to Apollo", Hesiod ("Hoíoঠos, fl. 700 BCE), Aeschylus (Aiøxúরos, 525-456 BCE), and Pindar (522 BCE to †443 BCE).

Zeus battled Typhon, inveterate enemy of the Olympian gods, and subdued him. One version says that Typhon threw what is now Mount Etna at Zeus and he deflected it, burying the monster under its mass. From his prison Typhon spews forth hot rocks and smoke. Thus, Typhon is the symbolic representation of volcanic forces.

Typhon, as the father of the Winds, causes dangerous storms. This deity's name is cognate with "typhoon," borrowed from the Arabic, Persian, and Urdu و وافن tufân (to turn around), and still in use to describe violent cyclonic storms of the Indian Ocean. Although typhōn and tufân are cognates, "typhoon" came into English from two directions (OED 2006). Typhoon also came from Cantonese tai fung (ta=big, fêng=wind). The Cantonese loaned into Portuguese left the cognate tufão.

An intriguing twist on this deity's name is that Murison (1905) thought that Typhon might be cognate with the Hebrew Șiph'oni, an obscure reference to what became known as the Basilisk. Murison claimed that Siph'oni has no etymological equivalent in Hebrew and might have been loaned to them from Egypt and Syria. Perhaps Șiph'oni is analogous to Hebrew פָָ Sephon [Saphon], "north," which was the abode of Set [Sutekh, Setesh, Seteh] ("the one of the wrappings"), who Herodotus (fl. 484 BCE) acknowledged was adopted from the Egyptians. Set, a Crocodilian divinity, dates from ca. 3150 BCE, and the classical Greeks (4th and 5th centuries BCE) wrote his name as Seth. Egyptians considered all animals that lived in water or spent part of their time in water to be associated with Set (Frazer 1890).

The Egyptians earlier had adopted their deity Set, with a name change, from the Sumerians who lived between ca. 6090-5429 calBCE (Encyclopedia Brittanica 2006, Lawler 2002, Wikipedia 2007). Herodotus knew the Greek chronicle had been adapted from the Egyptians, but what was unknown at his time was that the first written records of this story were created by the Babylonians. These documents, the Enûma Eliš, are estimated at having been written between the 14th and 12th centuries BCE, but surely the narrative is as old as $1800 \mathrm{BCE}$ when the Hittites first appear in archaeological records. Arnold (2004) estimated the composition of the tale at 3000-4000 BCE. The Hittite story of Marduk fighting the dragon Tiamat passed through Egypt to become the model for Zeus and Typhon (Blust 2000, Güterbock 1948, Lewis 1996, Walcot 1956).

Another related variant is the Hindu story of the killing of Vritra ("the enveloper," an asura or dragon) by Indra (also a lightning and weather deity) (Blust 2000, Wikipedia 2007). According to the Rig Veda, Vritra was an Ahi ("snake") dragon with three heads that gathered all the waters of the world and held them captive until he was defeated by Indra. Zahhāk [Zohhāk], the analogous dragon in Persian stories, was known in ancient Iranian folklore and in the Avesta as Aži Dahāka. Zeus and Indra are analogous to Thor (Norse) who killed the sea serpent Jörmungandr ['jœrmungandr] (Midgard Serpent), and Perun (Slavic) who overcame Велесъ (Veles [Volos], Old Russian) (e.g., Wikipedia 2007). Tiamat and Typhon are analogous to Jörmungandr and Велесъ; Cernunnos ("great horned one," Celtic) may be the same monster.

By contrast dragons of East Asia were largely benevolent. These beasts include the 龍 Long (Mandarin, 龙 Pinyin), 竜 Tatsu (Japanese), 룡/용 Ryong/Yong (Korean), มังกรจีน Mangkorn jihn (Thai), and Rồng (Vietnamese). The Chinese recognized a 虬龍 Jiaolong (horned dragon) reminiscent of those of the New World (Encyclopedia Brittanica 2006, Wikipedia 2007). All were wetland and ocean creatures that brought rain (Blust 2000). It is pertinent that the Chinese called Typha leaves the 龍䰅 lung sou [lóng xū, Mandarin] (dragon's beard) (Mathews 1944).

As an indication of the widespread incorporation into Old World views, Typha was included in Ainu riddles in Japan (Taylor 1947). The Ainu have a riddle that asks, "What looks at the setting sun from behind?" The answer: cattail.

The other spelling is Latin typhus (from Greek tũФoб). In English, "typhus" originally meant pride, haughtiness, or conceit, but by 1785 was applied to an infectious fever caused by Rickettsia. English-speakers call that fever "typhoid" (typhos=smoke, -oid=resembling) because of 


\section{Austin - Sacred Connections with Cat-tail (Typha, Typhaceae) - Dragons, water-serpents and reed-maces}

the smoky or lazy state of mind of those affected (OED 2006).

Another biblical reference that led to incorporation into the Christian religion was that of the crucifixion. The Bible states: "And they smote him on the head with a reed, and did spit upon him, and bowing their knees worshipped him" (Mark 15:19, King James Version, translated 16041611). The English came from the Latin Vulgate that was finished about 405 (Encyclopedia Brittanica 2007). The Vulgate has: "et percutiebant caput eius harundine et conspuebant eum et ponentes genua adorabant eum." Harundo, the basis of harundine, can mean reed, cane, fishing rod, limed twigs for catching birds, arrow shaft, or pipe. Oddly, the word harundo is not Latin but of Germanic derivation, having been taken from Old English hréod (OED 2006). Certainly, hréod gave rise to the modern English word "reed" (cf. Austin 2004). It is not known why Jerome (Eusebius Hieronymus, 347-419), who was born in what is now Croatia, used this word in the Hebrew to Latin translation. Biologists identify harundo as either Phragmites or Arundo (both Poaceae). Both Phragmites (Hebrew הנק kaneh) and Typha (Hebrew olq suf) grow in the area where the biblical events occurred, but either

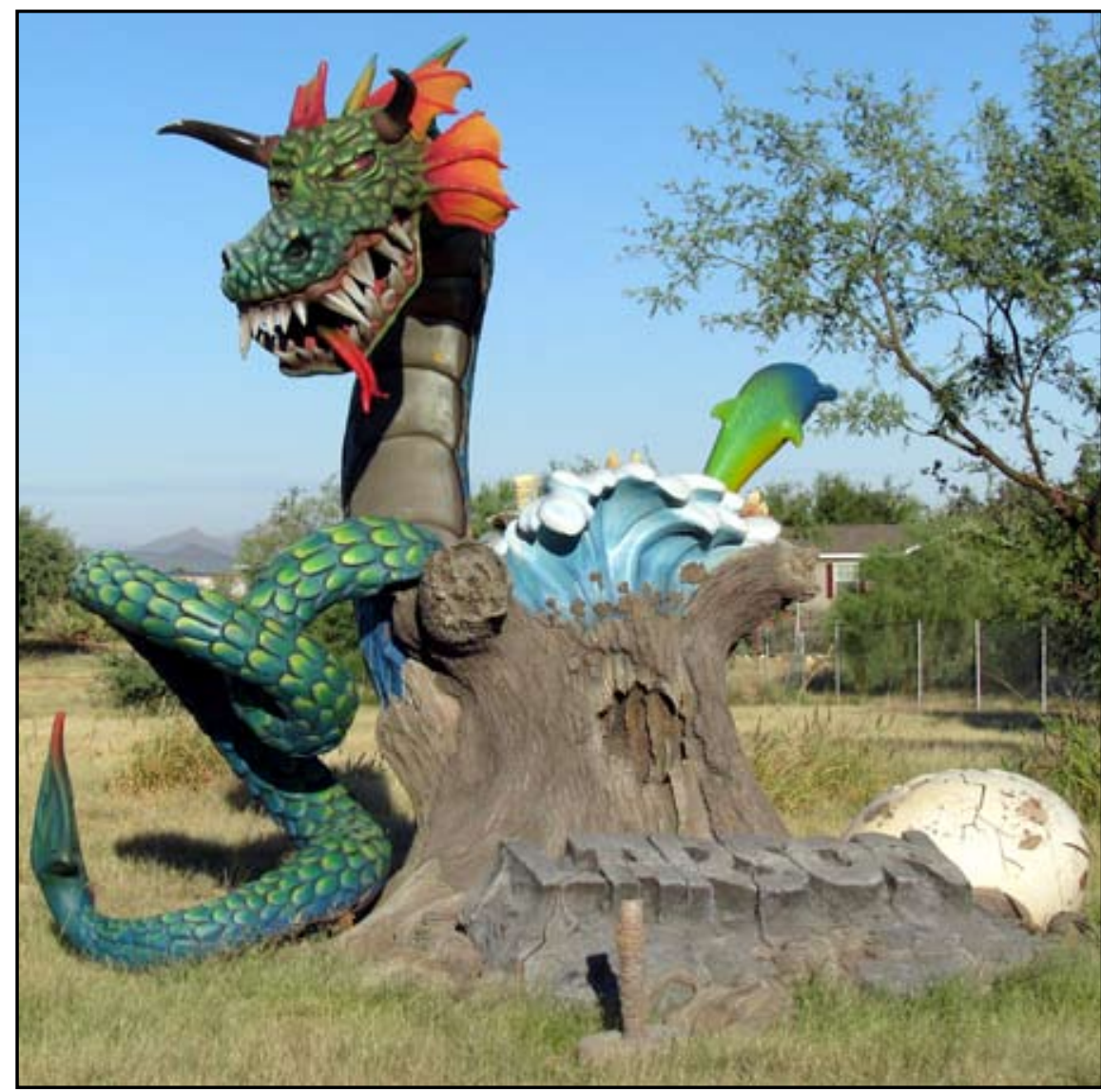

Figure 3. Modern dragon sculpture near Tucson, Arizona. On the slopes of the Sierrita Mountains, Pima Co.
Jerome did not know the meaning of oln or did not know that it was Typha.

Because of the Hebrew or Vulgate reference, the Christians of the Middle Ages (500-1500) began using cat-tails in artwork. Typha appears as part of the scenery in the tapestries of unicorns (Marquand 1938); both plant and animal were allusions to Christ. Paintings by Flemish artist Sir Anthony Van Dyck of Jesus' mock trial have him with a cat-tail in his hand as a scepter. Even Leonardo da Vinci included Typha (Meyer \& Glover 1989). Could this view be the basis for the name "reed-mace"?

The stories of dragons and cat-tails are variants on the same theme that date back to the rise of Eurasian and Asian cultures. Because the underworld dragons are associated with water and Typha may be the most frequent plant in the wetlands, all stories implicate dragons, water, and cat-tails as being connected. Some of the words used actually link them, e.g. Typhes, typhaeon, Zrggavera.

\section{New World Connections}

A widespread theme in indigenous American religions is that people emerged into the current world from an underworld or previous world (e.g., Hudson 1976, O'Bryan 1956, Saxton \& Saxton 1973, Wright 1988). Because that lower region is populated by monsters that were left behind when humans and other animals emerged, the nether area is to be placated. These fearsome things approach the surface through caves and wetlands. Important among these powerful beings are those called Water Serpents, Horned Serpents, Plumed Serpents, or some similar name (e.g., Awanyu, Tewa; Okikŏ:wî:, Mikasuki; Kolowisi <Kolowissi>, Zuni; Itzamna or Kukulkan, Maya; Mi॰?s-kenu•pik <Kinepíkwa>, Algonquin; Onyare, Mohawk; Palraiyuk, Eskimo; Paalölöqangw <Pálülükoñti, Palulokong, Palulukon>, Hopi; Piasa <Piasaw, Païssa>, Miami; Quetzalcoatl, Náhuatl; Sisiutl, Kwakiutl; Sinti'hollo' <Sintholo>, Chickasaw; Tiéholtsodi, Navajo; Uktena, Cherokee; Unkéegila <Unktéhi, Unktelii, 
Uhktena>, Lakota; U''-tken', Tuscarora; cf. Elliot Smith 1918, Fewkes 1893, Gatschet 1899, Gray 1922, Henson 1957, Hewitt 1889, 1909, Masthay 2003, Mundkur 1984, Sturtevant 1955, Swanton 1928). These powerful entities were part of the pantheon from the Eskimo (Gill \& Sullivan 1992 ) to the Iroquois of New England (Harrington 1906), the Chimakuan and Salishan people in the Puget Sound area (Ludwin et al. 2005), and south through the Tewa (Parsons 1926b), Hopi (Fewkes 1893), the Aztecs (Boyd 1996, Griffith 1990), the Maya (Boyd 1996), the Sumu of Nicaragua (Rands 1954), the Toba of Argentina (Méteaux 1946), and the Mapudungun [Mapuche] of Chile (Mundkur 1984). The Water Serpent dates to at least the Hopewellian people (ca. 200 BCE to CE 500) of the Mississippi Valley (Brown 1997). Many linguistic groups viewed the deities of the world above humans and those in the underworld as in constant conflict (e.g., Howard 1960, Hudson 1976). Humans needed to make gifts to both or the struggle might escalate and involve them.
A few examples illustrate the importance of Typha, as do its many names (cf. Appendix). Essentially, the genus has been vital from at least the Maya of Mexico and Central America through North America into the boreal zone. It was probably equally important in South America, but fewer data are available from there.

The Maya may be descendants of some of the first waves of people to reach the New World (Cavalli-Sforza et al. 1994). Links in Mayan languages, toponyms, and beliefs tie their past with Typha. Mayan writing includes the glyph sounded as pu(j) or puh (Boot 2002, Mathews \& Bíró 2006). Their classical name for Teotihuacan was Puh ("Place of Cat-tails"), and the word continues today (cf. Appendix). Sachse \& Christenson (2005) suggest that Tulan ("Place of Cat-tails") possibly dates to Olmec times (1200-600 BCE) and that the name is a metaphorical reference to a place of origin. For example, the Popul Vuh asserted that individual lineages of Mayans began at Tulan (Akkeren 2003). The K'iche' named their capi-

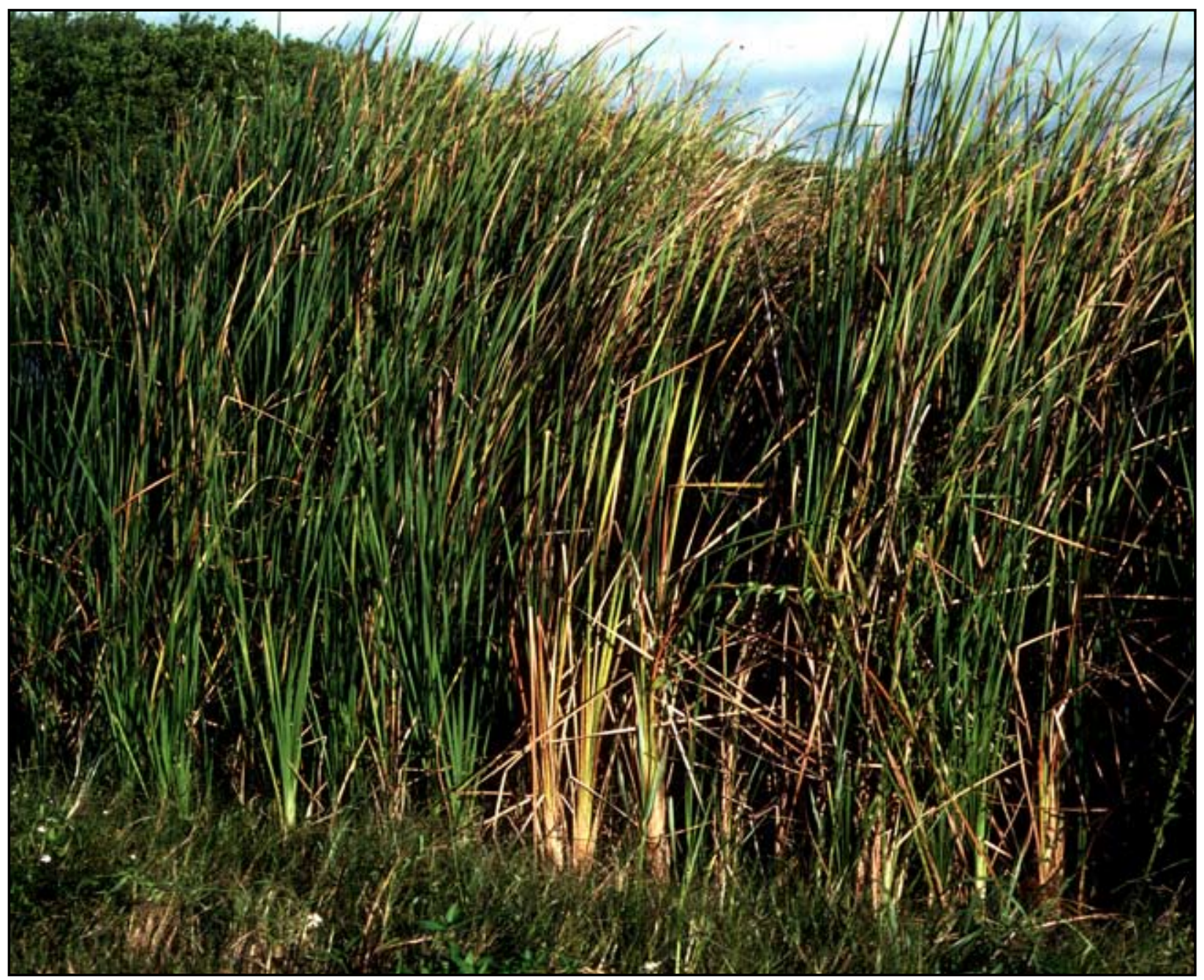

Figure 4. Typha stand in Collier Co., Everglades, Florida. 


\section{Austin - Sacred Connections with Cat-tail (Typha, Typhaceae) - Dragons, water-serpents and reed-maces}

tal Q'umarkaj ("Place of Ancient Cat-tails"). Tollan means the same in unrelated Náhuatl. Indeed, the name of the Toltecs who gave rise to the Aztecs is based on tollin (cat-tail) and teca (to exist, to be with) (Siméon 1885).

Several tribes have clans named for Typha. Among the Peigan Blackfoot they are the Aapáíaitapi (Franz \& Russell 1995); Cahuilla call theirs the Mi-ke-the-stse-dse (Cat-tail People) (Rollings 1995). Paiute have a Cat-tailEater clan (Fowler 1992) and San Juan Tewa had a Ye clan (Cat-tail) (Parsons 1924).

Takelma, Penutian people in Oregon, considered Typha a powerful plant. When someone wanted to end a heavy rain, they sang a song mentioning duyùm (cat-tail) (Sapir

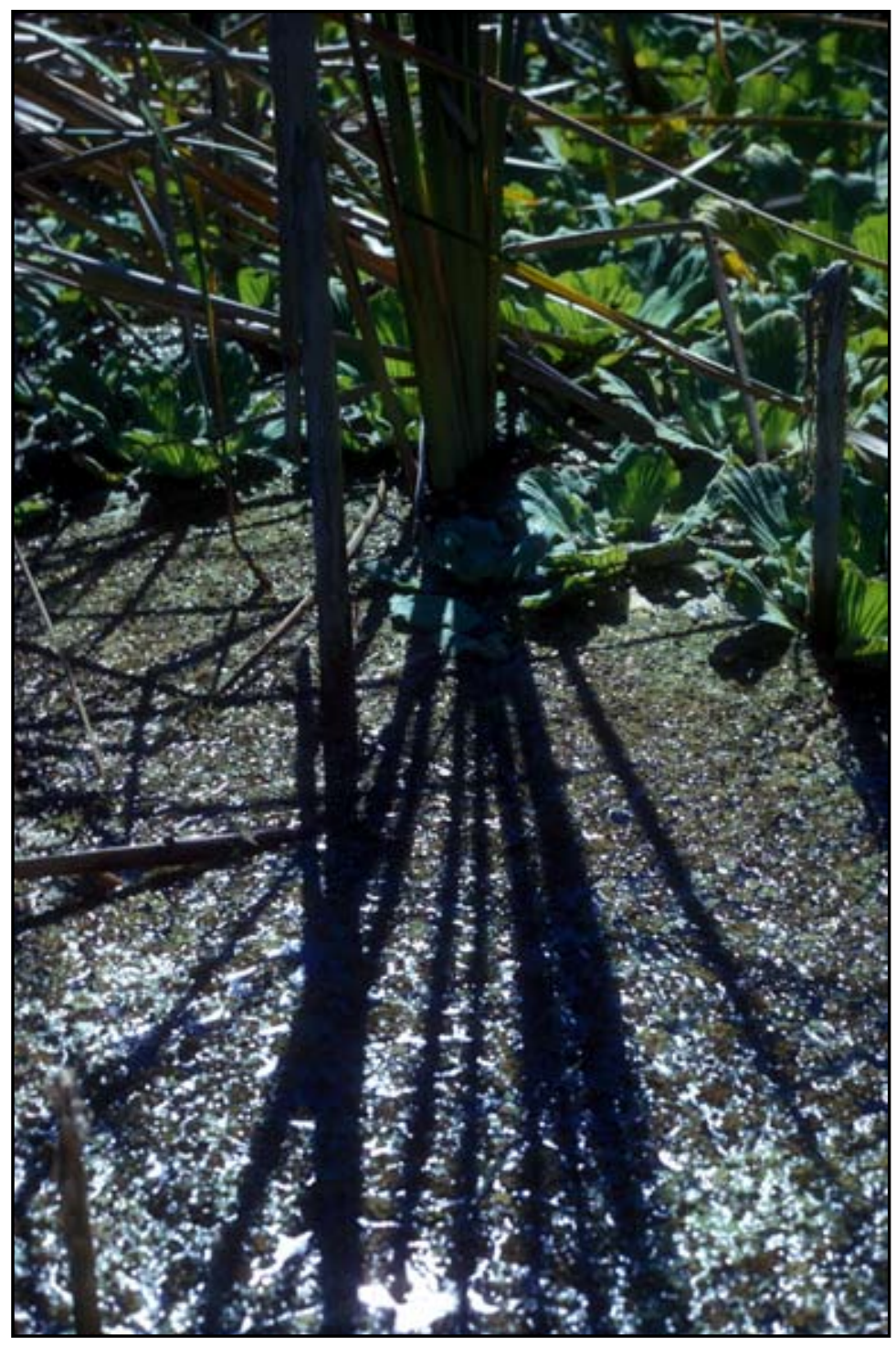

Figure 5. Cat-tail leaves reflected in water. With Pistia, Azolla, and Lemna floating on surface. Palm Beach Co., Everglades, Florida.

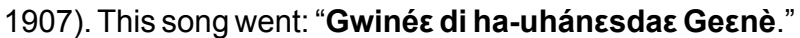
(To people in house). "Dīt'gāyúk!umāada duyùm عalp!ī its•!̄'lts•!alhip." ("How long is it before thou wilt cease? So long hast thou been raining! [To people in house]. Do you burn cat-tails toward the west?").

Cat-tail plays a pivotal role in the Mono story of Ninitikati (Walking Skeleton) of California where Typha helped a girl escape this monster (Gifford 1923). After Walking Skeleton had chased her and she had escaped several times, she arrived at an aunt's. This relative hid her in a basket covered with cat-tails. Eventually, she lived with Eagle and had a large number of children with him. These offspring gave rise to the Miwok, Mono, and Yokuts tribes.

In New England and Canada, the Abnaki tell of Raccoon who killed all but one of a family of juvenile Sables. Finally the father caught up to Raccoon in a wetland and tried to kill him. Raccoon told Sable "The only way you can do that is to hit me with a cat-tail stalk!" Sable did so, and Raccoon escaped because of a cattail (Speck 1935). A similar theme occurs in "How Glooslap conquered the Great Bullfrog" among the New England Micmac and Passamaquoddy (Leland 1884, Smith 1994). These Algonquian stories bear a striking resemblance to that of East Indian Vritra because the antagonists were hoarding water.

Others pay homage to the underworld by using cat-tail spikes, leaves, or other parts. Pointing to great religious importance and antiquity of cat-tails among New World people is Gilmore's (1909) comment that the Omaha "...display of sprays of the plant ... indicate the sacred character of the article or place with which it was connected."

Tribes in both Algonquian and Siouan language families had the Calumet or Pipe Ceremony. Although those languages families are unrelated, they share the word Wawan [Wáwa] for the ritual. Literally, wawan in Algonquian languages is "egg" (Michelson 1935, Proulx 1984 , Uhlenbeck 1924) and the ceremony is named that because it was an adoption event for redistribution of wealth (e.g., Alexander 1933, Dorsey 1896).

The niniba weawan or "pipe," was a critical part of the Wawan ceremony, and a cat-tail was essential for creating it (Gilmore 1919). The "pipe" was not made for smoking but had the head and neck of a duck (probably Mallard, Anas platyrhynchos L.) in place of the bowl (Dorsey 1896). The blue pipe-stem was 
a cat-tail (Gilmore 1919). Both the duck and Typha show reverence for the underworld. Another practice indicating that the Wawan was an old ceremony involving Typha is its mention in traditional stories and songs (Dorsey 1892).

Dunmire \& Tierney (1995) noted that Typha was used in ceremonies and dances at most Pueblos. To Pueblo people, the cardinal points may be indicated by plants. The Acoma have Typha as part of their origin story, and used leaves on prayer sticks as a symbol of the south (Stirling 1942). Tewa use the cat-tail to make the Bear Clan kachina mask mukwati (the old man). This mask is not of skin but of yucca with a "squash blossom" made of cat-tail on one side (Parsons 1926a).
The Hopi planted Typha with other plants near their homes (Whiting 1939). Not only do Hopi incorporate cattails as part of their concept of utopia (Hirschman 2002), but they also use a bundle of leaves and fruiting stalks in the Niman Kachina (also called Home Dance) at Hotevilla (2005 artifact with C. R. Szuter \& T. E. Sheridan), among other villages.

Acoma also include Typha in the story of the Pai'yatya'mo and Yellow Woman where he literally loses his heart to the K'o'tcininak' sisters; they cut it out, wrapped it in cattail fluff, and put it in a jar (Benedict 1930). This association of cat-tail fluff with death is similarly found among the Salish of the Pacific Northwest who buried their dead with it (Ostapkowicz et al. 2001).

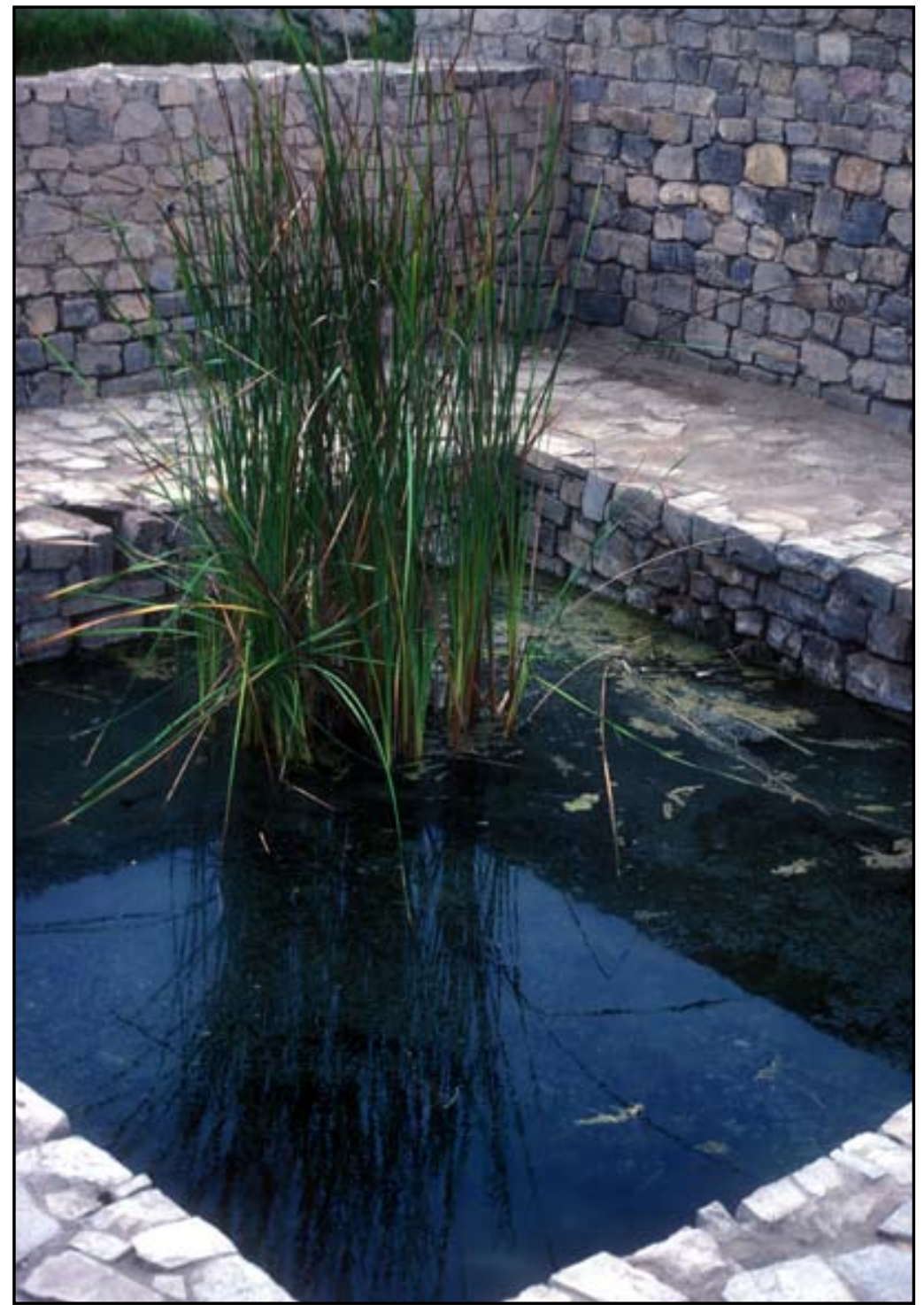

Figure 6. Typha in pool at ruins of Pachamac, near Lima, Peru.
An ancient offering to deities was pollen. Originally, the pollen was from cattails, and that remained a prime source for some tribes. Once maize (Zea mays L.) became established, pollen from that became culturally more important in some groups (e.g., Matthews 1902). Bourke (1892) pointed out that the people of the Pueblos uniformly used pollen as a blessing, with the Acoma and Laguna calling it hinawa. He does not clarify if they used pollen from Typha or maize.

Bourke (1892) recorded that the Zuni called "pollen" kunque. Stevenson (1915) did not mention cattails among the Zuni; neither did Cushing in Breadstuff (1920) or other publications. However, Wright (1988) noted that the Zuni considered Typha around springs as indicators of the supernatural, an allusion to their point of origin ("sipapu" or shípapolima).

Currently the Pueblo inhabitants bless with corn pollen or even cornmeal instead of cat-tail pollen. At least the Acoma, Hopi, Laguna, Isleta, Western Keres, and Zuni consider pollen an important element in rituals (Bourke 1892, Jones 1931, Swank 1932). Hill (2002) suggested that maize cultivation came to the Southwest and onto the Colorado Plateau between 4000 and 3000 years ago (1500-1000 BCE). Huckell \& Toll (2004) found that maize agriculture was integrated with plant gathering by those dates. If dated correctly, then the persistence of cat-tail pollen as a ritual blessing into the present points to its historical importance. 


\section{Austin - Sacred Connections with Cat-tail (Typha, Typhaceae) - Dragons, water-serpents and reed-maces}

The last groups to arrive in the Southwest were Apacheans (Indé, Apache and Diné, Navajo). These two cultures migrated into Arizona and New Mexico from the north during the 1400s or 1500s (Ezell 1983, Hoijer 1956, Wilcox 1981).

The Diné origin account clarifies the fundamental nature of pollen. According to that saga, "The Creator had a thought that created Light in the East. Then the thought went South to create Water, West to create Air, and North to create Pollen from emptiness. This Pollen became Earth" (Smith 1998). O'Bryan (1956) provided a similar version. Apaches called pollen hadndín <hadídíin> (Bourke 1891, 1892), and they believed that it was scattered along the face of the heavens to form the Milky Way. Pollen was used in all their ceremonies (Bourke 1891, Farish 1918), and originally both Apaches and Navajo used cat-tails (Matthews 1902). Although Navajo have now largely replaced Typha with corn (O'Bryan 1956), several ceremonies still require cat-tail pollen (Elmore 1944, Vestal 1952).

Sometimes pollen was prepared by putting live animals into it (Matthews 1902). The animals must be released alive after being used or the pollen was considered "dead." Bluebirds (probably Sialia), yellow warblers (Dendroica petechia L.), and hummingbirds were particularly favored, but grasshoppers were also employed. Even the tiníléí <tińlé•i> (Gila monster, Navajo) was used (Wyman 1936b). Pollen thus prepared took on the energy and spirit of the temporary captive. This practice dates into the deep past and is included in the origin story of the Navajo where the young water monsters (tééhoodtsódii <tiéholtsodi>; tééh, deep water, hoołtsóód, it grabs, ii, the one) were covered with pollen before being released (Matthews 1902). This blessing with pollen was believed to bring rain, game, and good fortune.

Colors are associated with directions among many preEuropean people in the New World. The color indicating a particular direction varies with tribe, but two examples suffice to show the general association (Lamphere 1969). Among the Navajo, the west is indicated by yellow and teeł tádidíin <tquel tqa-di-tin'> (yellow pollen, literally "cat-tail pollen") was the original blessing material (Matthews 1902). Blue is associated with the south and tádidín dootł'izh <txatitịi'tootł'ij> (blue pollen, ground flowers of Delphinium) denotes that connection and invokes the benevolence of spirits from that region (Matthews 1886, 1902, Wyman \& Harris 1941).

A small sack of pollen was given to every Apache child born, and hadndín was carried by warriors (Bourke 1891, 1892). When a rattlesnake was encountered, it was customary to throw a pinch of hadndín on its trail and request that it be good and return to its home (Bourke 1891). Pollen was spread on the ill, their attendants and family, and on the diyinn <izzénantan> (shaman). Other items were similarly blessed with cat-tail pollen, including medicine cords (Day 1950). Medicine cords often contained stone "arrowheads" used by earlier cultures that the Apaches and Navajos consider lightening "arrows" or "thunder's knife" (Day 1950, Young \& Morgan 1980). Sometimes, the cords also contained fragments of lightning-splintered wood. During storms, both tribes sprinkled pollen and admonished the lightening to behave (Hildburgh 1919, Begay \& Maryboy 2000). Indeed, pollen served as a blessing to aid prayers to all things supernatural or at least powerful.

Navajos are famous for their many ceremonies, and pollen was an integral part of old and modern events (Haile 1938). Among those requiring cat-tail pollen are the Níłch’ijí NoodoQ̨óźjí <ńłč'izí nodǫzzí> (Striped Windway, which is a Tí'díłt'é Hatáál, injuryway) (Wyman \& Bailey 1946), Deer Windway and Níłch'ijí Ńlóee (Hail Windway) (both Hózhọójí Hatáál, peacefulway chantswith-pollen), Talking God (Haashch'ééłti'í) Earth Song (a Hózhọójík'ehgo, blessingway) (Wyman \& Bailey 1945), and the Na'at'oyee Biką'jí (Male Shootingway; to appease thunder and lightning) (Elmore 1944). In the Male Shootingway not only is pollen employed but necklaces and wristbands are made of Typha leaves (Mayes \& Lacy 1989). Perhaps the Navajo considered Typha too powerful to consume, as they reportedly never ate it (Mayes \& Lacy 1989).

Cat-tail pollen was used among the Apache in the early 1900s during the Christian-influenced event called dahgodiyáh (they will be raised up) (Goodwin \& Kaut 1954). Even now, the Apache gather hadídín and manage their lands to assure its availability (Long et al. 2003). Pollen was at least a blessing if not a component of sandpaintings among both Apache and Navajo (e.g., Matthews 1885, Russell 1898).

\section{Discussion}

Linnaeus (1753) delighted in using words with multiple meanings and origins for generic names and achieved that goal when he used Typha for cat-tails. Typha has historically been interpreted as being from Greek typhos (marsh). While that is correct, the word also may be interpreted as from Typhe (smoke, from typhein) and Typhon (the dragon). The other derivations show that the association with humans is markedly more complex than previously thought.

Reminiscent of cacao (Theobroma) and maize (Zea), cattail evokes dyads of views from people-common and treasured, staple and tribute, profane and sacred (McNeil 2007). Typha in and of itself is no more significant than other plants that play roles in people's lives. However, as with frogs, snakes, and turtles, the fact that cat-tail grows in wetlands caused humans around the world to associate it with the powerful and fearsome beings that inhabit 
the underworld. That association is because people consider caves and wetlands to be gateways or portals to the nether regions. The various versions and beliefs bear a remarkable resemblance to each other and may result from evolution of beliefs and diversification held before humans reached the New World. The position that they are homologous has been held by many (e.g., Bengtson 1994, Bourke 1891, Elliot Smith 1918, Mundkur 1984, Steward 1960, Wilson 2005). Blust (2000) argued that belief in dragons may be tens of thousands of years old but that, as people dispersed over the earth, they changed the basic concept differently by modifying it to reflect local biotas. The same antiquity and evolution must be true with Typha.

Since at least the time of the people who gave rise to the Indo-Europeans, Typha was used as an allusion to the nether region. Virtually all religions make ample use of symbolism, and this plant lent itself admirably to that purpose-particularly when people believed that saying the name of a specific spirit or being might draw its attention to them and result in harm.

Reference to the underworld was accomplished in several ways. The fact that the Greeks called cat-tail typhe indicated that they connected it with the nadir. That relationship was through comparison to an important supernatural being who showed his presence by sending smoke to the surface through volcanoes and in storms. The Greeks called him Typhon, and he was visualized as a serpentlike dragon. This monster has analogs across Europe, Africa, Asia, and Australia (Blust 2000).

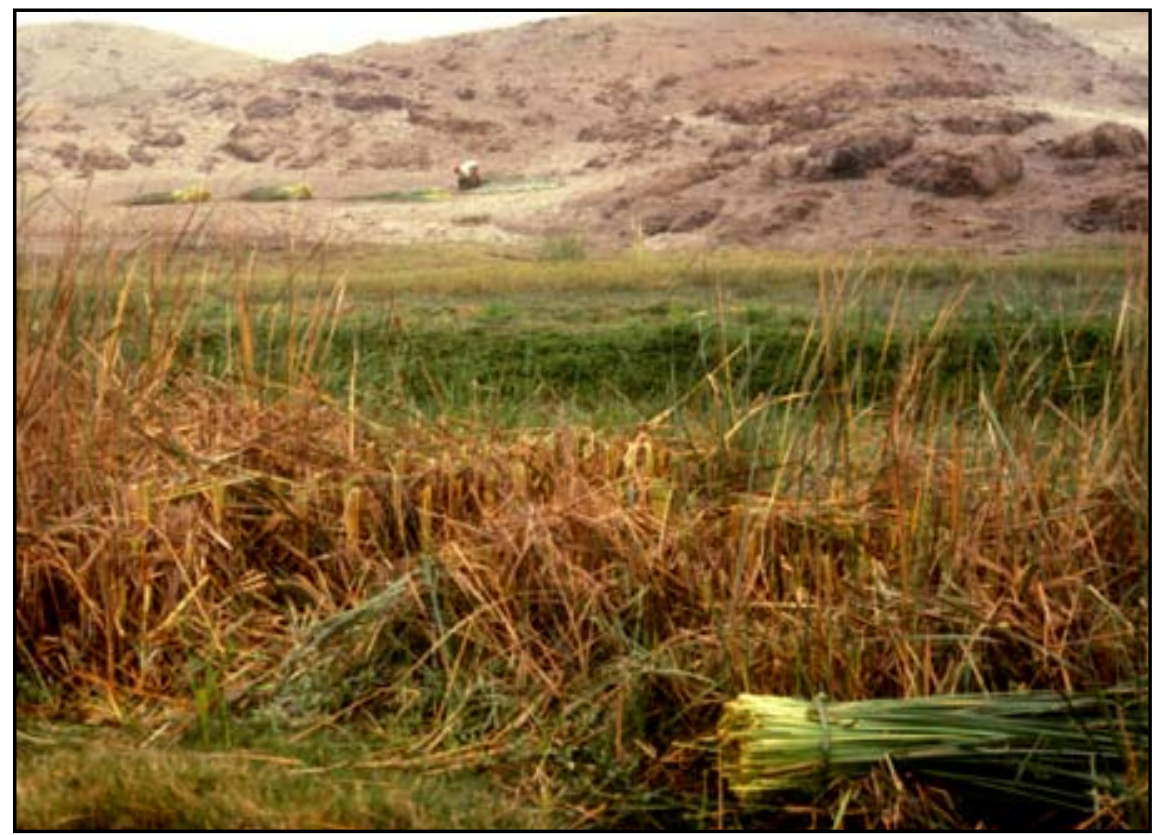

Figure 7. Totora (Cat-tail) leaves being gathered in marsh. Cañete, Peru.
Belief in dragons and serpent-like creatures circles the world, but the shape and abilities of the beasts vary with language and culture (Blust 2000). In Asia, these are mostly benevolent creatures, although some were malevolent—like the Japanese Yamata no Orochi (八岐の大蛇, big snake of eight branches). Dragons are famous for destructive activities among Western cultures, and legends, stories, and books in Europe are rife with them, e.g., Tolkiens' trilogy, Y Ddraig Goch ("the red dragon" in Welsh), Níohöggr ("malice striker" in Norse), and Harry Potter books. Arguably, the oldest name for Typha in southern Asia is Sanskrit Zrggavera, a serpent-demon. New World dragons are Horned or Plumed or Water Serpents. These are part of the pantheon of people from the Eskimo to at least those of the Gran Chaco of Argentina and Mapudungun of Chile.

The number of simple names of Typha attests to great age of association with humans. Even in languages where there are simple terms for cat-tails, there may be others that are probably of more recent application. Newer names may exist because the indigenous people no longer remember the simple terms, or because they have withheld those names for some reason. One reason for not revealing a sacred name might include name taboos. Even the compound names that may be broken into components often include elements that are simple.

Simply displaying a bundle of leaves and fruit-spike during the Niman Kachina of the Hopi also appeals to underworld inhabitants. Inclusion of a fruit stalk among the Algonquian and Siouan people is another power-invocation.

Color is a more abstract allusion. For example, blue and yellow were associated with south and west among the Navajo. Both colors are symbolical links with nature, blue with evening twilight and blue sky, yellow with cornmeal and pollen. At another level, the colors are the symbolic emblems of peace, prosperity, and happiness.

Several references to pollen among the Navajo trace to their origin narratives. In that oratory when a war-god bids his enemy to put his feet in pollen, he compels them to peace. When a Night Chant devotee prays, "Happily on a trail of pollen, may I walk," they are requesting a happy and peaceful life (Sanders 1973). The statement im- 


\section{Austin - Sacred Connections with Cat-tail (Typha, Typhaceae) - Dragons, water-serpents and reed-maces}

plies some kind of pollen-it may be general or a specific plant.

Pollen from cat-tails is an obvious way to invoke a blessing from power-carriers. Since pollen became Earth in origin stories, and Earth represents the Earth Mother or 'Asdząą' Nádleehé (Changing Woman) to the Navajo, pollen invokes her blessing. She is beneficent, loves humans, and sends the rains of summer and spring thawing. Changing Woman is the deification of fruitful nature, and pollen use requests these blessings. Navajo sacred speech and songs speak of haze and the smoky dimness of the horizon due to materials in the air like pollen. This is a reference to pollen as emblematic of the morning and evening stars.

"Pollen" among some indigenous Americans is not always the male plant gametophyte. Some deem dust in the air as "pollen." Others considered the yellow material gathering on pool and spring surfaces "water pollen," although in that case they were incorrect only about its source-it came from wind-pollinated trees like pines (Pinus). This generalized view of the close nature of "pollen" and other power-fragments of the Earth is an ancient concept spanning the earth, as is that of dragons or water-monsters. While Bourke (1892) made a number of spurious comparisons of pollen with several New and Old World peoples (e.g., tzohualli, now known to be seeds of Chenopodium, cf. Austin 2004), he made others that are intriguing. He quotes from studies of East Indian, Egyptian, Japanese, and Ojibwa uses of pollen as a blessing item. There are several references among these to the regeneration powers of pollen. All of this symbolism suggests long belief in the power inherent in pollen or other "dusts," including bird down. This aspect needs to be explored.

Another aspect needing investigation is why Typha was selected from the other wetlands plants, or indeed, if it was singled out as most important. Can it be that people consider the cat-tail a special indicator of the nether world more important than the remaining wetland species? If so, why? Names of some other wetland plants among the Navajo appear to suggest that they considered Typha more important or elemental than others. For example, Eleocharis montevidensis Kunth is teeł ts'ósí (slender cattail), E. palustris (L.) Roem. \& Schult., E. rostellata (Torr.) Torr. and Scirpus acutus Muhl. ex Bigelow are teeł níyiz (round cattail), and both Iris missouriensis Nutt. and Triglochin maritima L. are teed dikan (sweet cat-tail) (Wyman \& Harris 1941, Vestal 1952). All six of these plants are used in the Lightningway healing ceremony (Vestal 1952) which contends that the infirm person has been impacted by being near a lightening strike (Wyman \& Kluckhorn 1938, Begay \& Maryboy 2000). Clearly there are other views and factors needing elucidation.

At the time Theophrastus and Dioscorides were writing down the Greek names for cat-tails, some of these connections were unknown. When Linnaeus (1753) created the genus Typha, he might have been unaware of the many allusions the Greek words contained, but that appears unlikely. Subsequent to Typha naming in 1753, the knowledge of Greek and Latin myths was lost among most scholars in the disciplines of anthropology and botany. For example, in an otherwise excellent paper, Griffith (1990) speculated that the people of the Americas provided Europeans with their only source of beliefs in water monsters. Europeans imported a surfeit of dragon stories and the American views only augmented those beliefs. In an etymological sense, Typha is the offspring of multiple cultures.

\section{Acknowledgments}

I thank the following people for aid in the topics listed: Jim Duke (references and names), Eckart Eich (German), Kaoru Kitajima (Japanese), Anita and Keijo Korhonen (Finnish), Jack B, Martin (Muskogean), Pamela Munro (Chickasaw), My Lien Nguyen (Vietnamese), Ildiko Palyka (Hungarian), Nancy J. Turner (Athapascan), Alejandro Velasco-Levy (Spanish), and Valeria Volin (Italian). Mary Stiffler (Missouri Botanical Garden Library) aided with references. J. Andrew McDonald, David L. Shaul, Thomas E. Sheridan, Nancy J. Turner, and Daniel B. Ward reviewed a draft and provided helpful suggestions.

\section{Literature Cited}

AISRI. 2007. Indian Dictionary Database. American Indian Studies Research Institute. www.indiana.edu/ aisri/ search/index.shtml.

Akkeren, R.W. van. 2003. Authors of the Popol Wuj. Ancient Mesoamerica 14:237-256.

Albert, R. \& D.L. Shaul. 1985. A concise Hopi and English Lexicon. John Benjamins, Philadelphia, PA.

Alcorn, J.B. 1984. Huastec Mayan Ethnobotany. University Texas Press, Austin, TX.

Alexander, H.B. 1933. Francis La Flesche. American Anthropologist, New Series 35(2):328-331.

American Heritage Dictionary of the English Language. 2000. www.bartleby.com/61/.

Anderson, E.N., C.J. Cauich, A. Dzib, G.S. Flores, G. Islebe, T.F. Medina, S.O. Sánchez \& P. Valdez. 2003. Those Who Bring the Flowers: Maya Ethnobotany in Quintana Roo, Mexico. El Colegio de la Frontera Sur, Chiapas, México.

Arenas, P. \& G.F. Scarpa. 2003. The consumption of Typha domingensis Pers. (Typhaceae) pollen among the 
ethnic groups of the Gran Chaco, South America. Economic Botany 57(2):181-188.

Arnold, B.T. 2004. Who Were the Babylonians. Brill, Leiden. books.google.com/books?id=RIT-pWbkWKoC\&d $\mathrm{q}=$ Who+Were+the+Babylonians

Atsma, A.J. 2007. The Theoi Project: Guide to Greek mythology. www.theoi.com.

Austin, D.F. 2004. Florida Ethnobotany. CRC Press, Boca Raton, FL.

Balick, M.J., Nee, M.H., \& Atha, D.E. 2000. Checklist of the Vascular Plants of Belize: With common names and uses. New York Botanical Garden Press, Bronx, NY.

Bean, L.J. \& K.S. Saubel. 1972. Temalpakh: Cahuílla Indian knowledge and usage of plants. Malki Museum Press, Morongo Indian Reservation, Banning, CA.

Beauchamp, W.M. 1902. Onondaga plant names. The Journal of American Folklore 15(57):91-103.

Begay, D.H. \& N.C. Maryboy. 2000. The whole universe is my cathedral: A contemporary Navajo spiritual synthesis. Medical Anthropology Quarterly 14(4):498-520.

Benedict, R. 1930. Eight stories from Acoma. The Journal of American Folklore 43(167):59-87.

Bengtson, J.D. 1994. Edwar Sapir and the 'Sino-Dene' hypothesis. Anthropological Science 102(3):207-230.

Blench, R.M. 2006. Hausa names for plants and trees. rogerblench.info/Ethnoscience data/Hausa plant names. pdf.

Blust, R. 2000. The origin of dragons. Anthropos 95:519536.

Bocek, B.R. 1984. Ethnobotany of the Costanoan Indians, California, based on collections by John P. Harrington. Economic Botany 38(2):240-255.

Bolles, D. 1997. Combined Dictionary-Concordance of the Yucatecan Mayan Language. www.famsi.org/reports/96072/index.html.

Boot, E. 2002. A Preliminary Classic Maya-English/English-Classic Maya Vocabulary of Hieroglyphic Readings. www.mesoweb.com/resources/vocabulary/Vocabulary. pdf.

Bourke, J.G. 1891. Notes upon the religion of the Apache Indians. Folklore 2(4):419-454.
Bourke, J.G. 1888. The medicine-men of the Apache. Ninth Annual Report of the Bureau of Ethnology. Smithsonian Institution, Washington, DC.

Boyd, C.E. 1996. Shamanic journeys into the otherworld of the Archaic Chichimec. Latin American Antiquity $7(2): 152-164$.

Bray, D. 1998. Editor of Western Apache-English Dictionary: A community-generated bilingual dictionary. Bilingual Review/Press, Tempe, AZ.

Brown, J.A. 1997. The archaeology of ancient religion in the Eastern Woodlands. Annual Review of Anthropology 26:465-485

Budge, E.A.W. 1920. An Egyptian Hieroglyphic Dictionary. Reprinted 1978, Dover Publications, New York.

Callaghan, C.A. 2001. More evidence for Yok-Utian: A reanalysis of the Dixon and Kroeber sets. International Journal of American Linguistics 67(3):313-345.

Castetter, E.F. \& M.E. Opler. 1936. Ethnobiological studies in the American Southwest III: The ethnobiology of the Chiricahua and Mescalero Apache. University of New Mexico Bulletin 4(5):1-63.

Castetter, E.F. \& W.H. Bell. 1951. Yuman Indian Agriculture: Primitive subsistance on the Lower Colorado and Gila Rivers. University of New Mexico Press, Albuquerque, NM.

Castilhos de Araujo Cypriano, D.C. 2000. Os Toba do Chaco: Misão e identidade. Séculos XVI, XVII e XVIII. Thesis, Universidade do Vale do Rio dos Sinos, São Leopoldo, Brazil.

Cavalli-Sforza, L.L., P. Menozzi, \& A. Piazza. 1994. The History and Geography of Human Genes. Abridged Paperback Edition. Princeton University Press, Princeton, NJ.

Chamberlin, R. V. 1911. The ethno-botany of the Gosiute Indians of Utah. Memoirs of the American Anthropological Association 2(5):331-405.

Christensen, A.J. 2003. K'iche'-English Dictionary and Guide to Pronunciation of the K'iche'-Maya Alphabet. www.famsi.org/mayawriting/dictionary/christenson/quidic_complete.pdf.

Crawford, J.M. 1989. Cocopa Dictionary. University of California Publications in Linguistics. Volume 114. University of California Press, Berkeley, CA.

Conklin, H.C. 1962. Lexicographical treatment of folk taxonomies. Reprinted in Kupers, J. \& R. McDermott. 2007. 


\section{Austin - Sacred Connections with Cat-tail (Typha, Typhaceae) - Dragons, water-serpents and reed-maces}

Editors of Fine Description: Ethnographic and linguistic essays by Hal Conklin. Monograph 56, Yale Southeast Asia Studies. New Haven, CT.

Corominas, J. 1954-1957. Diccionario Crítico Etimológico de la Lengua Castellana. Biblioteca Románica Hispánica, V. Diccionarios Etimologicos. Gredos, Madrid.

Correll, D.S. \& H.B. Correll. 1972. Aquatic and Wetland Plants of Southwestern United States. Environmental Protection Agency, Water Pollution Control Research Series 16030 DNL 01/72, Washington, DC.

Couper, R.A. 1951. The spore and pollen flora of the Cocos-bearing beds, Mangonui, North Aukland. Transactions and Proceedings of the Royal Society of New Zealand 79(3/4):340-348.

Curtin, L.S.M. 1947. Healing Herbs of the Upper Río Grande. Laboratory of Anthropology, Santa Fé, NM.

Curtin, L.S.M. 1949. By the Prophet of the Earth. Ethnobotany of the Pima. Reprinted 1984 by University of Arizona Press, Tucson, AZ.

Curtin, L.S.M. 1957. Some plants used by the Yuki Indians of Round Valley, Northern California. The MasterKey 31:85-94.

Curtis, E.S. 1907-1930. The North American Indian: Being a series of volumes picturing and describing the Indians of the United States and Alaska. The University Press, Cambridge, MA.

Cushing, F.H. 1920. Zuni Breadstuff. Reprinted 1974, Museum of the American Indian, Heye Foundation, New York.

Day, C.L. 1950. Knots and knot lore. Western Folklore 9(3):229-256.

Dayley, J. P. 1989. Tümpisa (Panamint) Shoshone Dictionary. University of California Publications in Linguistics. Volume 116. University of California Press, Berkeley.

Densmore, F. 1928. How Indians use Wild Plants for Food, Medicine and Crafts. Reprinted 1974, Dover Publications, Inc., New York.

Dorsey, J.O. 1892. Nanibozhu in Siouan mythology. The Journal of American Folklore 5(19):293-304.

Dorsey, J.O. 1896. Omaha Dwellings, Furniture and Implements. Thirteenth Annual Report of the Bureau of American Ethnology to the Secretary of the Smithsonian Institution 1891-1892. Government Printing Office, Washington.
Duke, J.A. 1972. Isthmian Ethnobotanical Dictionary. Published by the author. Fulton, Maryland.

Dunmire, W.W. \& G.D. Tierney. 1995. Wild Plants of the Pueblo Province. Exploring Ancient and Enduring Uses. Museum of New Mexico Press, Santa Fe, NM.

Elliot Smith, G. 1918. An American dragon. Man 18:161166.

Elmore, F. H. 1944. Ethnobotany of the Navajo. University of New Mexico Bulletin. Monograph series. No. 392 1(7):1-136.

Encyclopedia Brittanica. 2006. Academic Edition. www. britannica.com.

Ezell, P.H. 1983. History of the Pima. Pp. 149-160 in Southwest. Handbook of North American Indians, Volume 10. Edited by A. Ortiz. Smithsonian Institution, Washington, DC.

Farish, T.E. 1918. History of Arizona. The Filmer Brothers Electrotype Co., San Francisco.

Felger, R.S. \& Broyles, B. 2007. Editors of Dry Borders: Great natural reserves of the Sonoran Desert. University of Utah Press, Salt Lake City, Utah.

Felger, R.S. \& Moser, M.B. 1985. People of the Desert and Sea: Ethnobotany of the Seri Indians. University Arizona Press, Tucson, AZ.

Fewkes, J.W. 1891. A suggestion as to the meaning of the Moki snake dance. The Journal of American Folklore 4(13):129-138.

Fewkes, J.W. 1893. The Pá-lü-lü-koñ-ti: A Tusayan ceremony. The Journal of American Folklore 6(23):269-284.

Fowler, C.S. 1992. In the Shadow of Fox Peak: An ethnography of the Cat-tail-Eater Northern Paiute People of Stillwater Marsh. Cultural Resources Series No. 5. U.S. Fish and Wildlife Service, Portland.

Frantz, D. \& Russell, N.J. 1995. Blackfoot dictionary of stems, roots and affixes. University of Toronto Press, Toronto.

Frazer, J.G. 1890. The Golden Bough: A study in comparative religion. Macmillan, London.

Gatschet, A.S. 1899. Water-monsters of American aborigines. The Journal of American Folklore 12(47):255-260.

Ghazanfar, S.A. 1994. Handbook of Arabian Medicinal Plants. CRC Press, Inc., Boca Raton, FL. 
Gifford, E.W. 1923. Western mono myths. The Journal of American Folklore 36(142):301-367.

Gill, S.D. \& I.F. Sullivan. 1992. Dictionary of Native American Mythology. ABC-CLIO Inc., Santa Barbara, CA.

Gilmore, M.R. 1909. A Study of the Ethnobotany of the Omaha Indians. M.A. Thesis. University of Nebraska, Lincoln. www.rootsweb.com/ neresour/OLLibrary/collections/vol17/v17p314.htm.

Gilmore, M.R. 1919. Uses of Plants by the Indians of the Missouri River Region. Reprint 1977, with forward by Hugh Cutler. University of Nebraska Press, Lincoln.

Goetz, D. \& S.G. Morley. 1954. The Book of the People: Popul Vuh. Translated into English from Adrián Recino's translation from Quiché into Spanish. Plantin Press, Los Angeles.

Goodwin, G. \& C. Kaut. 1954. A native religious movement among the White Mountain and Cibecue Apache. Southwestern Journal of Anthropology 10(4):385-404.

Gordon, R.G., Jr. 2005. Editor of Ethnologue: Languages of the World, Fifteenth edition. SIL International, Dallas, TX. www.ethnologue.com.

Gray, L.H. 1922. The Indian god Dhanvantari. Journal of the American Oriental Society 42:323-337.

Griffith, J.S. 1990. Quetzalcoatl on the border? Mestizo water serpent beliefs of the Pimaría Alta. Western Folklore 49(4):391-400.

Güterbock, H.G. 1948. The Hittite version of the Hurrian Kumarbi myths: Oriental forerunners of Hesiod. American Journal of Archaeology 52(1):123-134.

Haile, B. 1938. Navaho chantways and ceremonies. American Anthropologist 40(4):639-652.

Harrington, M.R. 1906. Da-ra-sa-kwa. A Caughnawaga Legend. The Journal of American Folklore 19(73):127129.

Hedrick, U.P. 1919. Editor of Sturtevant's Notes on Edible Plants. J. B. Lyon Co., Albany, NY.

Henson, C.E. 1957. Ritual elements in Mississippi River petroglyphs. Folklore 68(3):405-410.

Hewitt, J.N.B. 1889. Serpent symbols. American Anthropologist 2(2):179-180 in Gilbert, G.K., P. Tracy, J.O. Dorsey, L. Fison \& J.N.B. Hewitt. 1899. Notes and News. American Anthropologist 2(2):173-180.
Hewitt, J.N.B. 1909. The Pajaritan culture. American Journal of Archaeology 13(3):334-344.

Hildburgh, W. L. 1919. On the flint implements attached to some Apache "Medicine Cords." Man 19:81-87.

Hill, J.H. 2002. Toward a linguistic prehistory of the Southwest: "Azteco-Tanoan" and the arrival of maize cultivation. Journal of Anthropological Research 58(4):457-475.

Hirschman, E.C. 2002. Metaphors, archetypes, and the biological origins of semotics. Semiotica 142(1):315-349.

Hodgson, W. 2001. Food Plants of the Sonoran Desert. The University of Arizona Press, Tucson, AZ.

Hoijer, H. 1956. The chronology of the Athapaskan languages. International Journal of American Linguistics 22(4):219-232.

Howard, J.H. 1960. When they worship the underwater panther: A Prairie Potawatomi bundle ceremony. Southwestern Journal of Anthropology 16(2):217-224.

Huckell, L.W. \& M.S. Toll. 2004. Wild plant use in the North American Southwest. Pp. 37-114 in Plants and People in Ancient Western North America. Edited by P.E. Minnis. Smithsonian Books, Washington, DC.

Hudson, C. 1976. The Southeastern Indians. University of Tennessee Press, Knoxville.

Jessop, J. 1981. Editor of Flora of Central Australia. Reed Books Pty. Ltd., Sydney.

Jones, V.H. 1931 The Ethnobotany of the Isleta Indians. M.A. Thesis. University of New Mexico.

Keller, J. 2001. Mansfeld's World Database of Agricultural and Horticultural Crops. mansfeld.ipk-gatersleben.de/ Mansfeld.

Klooster, C.I.E.A. van't, J.C. Lindeman \& M.J. Jensen-Jacobs. 2003. Index of vernacular plant names of Suriname. Blumea Supplement 15:1-322.

Lacombe, A. 1874. Dictionnaire de la Langue des Cris. C. O. Beauchemin \& Valois, Montréal.

Lamphere, L. 1969. Symbolic elements in Navajo ritual. Southwestern Journal of Anthropology 25(3):279-305.

Laughead, G. Jr. 1997. Potawatomi Dictionary. www.kansasheritage.org/PBP/books/dicto/d_frame.html.

Lawler, A. 2002. Report of oldest boat hints at early trade routes. Science 296(5574):1791-1792. 


\section{Austin - Sacred Connections with Cat-tail (Typha, Typhaceae) - Dragons, water-serpents and reed-maces}

Le Cointe, P. 1947. Amazonia Brasileira III. Arvores e Plantas Uteis. Companhia Editora Nacional, São Paulo.

Leland, C.G. 1884. The Algonquin legends of New England or, Myths and Folk Lore of the Micmac, Passamaquoddy, Penobscot Tribes. Houghton, Mifflin \& Company, Boston. Reprinted 1992 as Algonquin Legends. Dover Publications, Inc., NY.

Lentz, D.L. 1993. Medicinal and other economic plants of the Paya of Honduras. Economic Botany 47:358-370.

Lewis, T. J. 1996. CT 13.33-34 and Ezekiel 32: Lion-dragon myths. The Journal of the American Oriental Society 116(1):28-47.

Lexiteria. 2004-2007. North American Languages (from Alpha Dictionary). www.alphadictionary.com/directory/ Languages/North_American_Languages.

Linnaeus, C. 1753. Species Plantarum. 2 vols. Facsimile edition with introduction by W. T. Stearn, 1957. Ray Society, London.

Linskens, H.F. \& W. Jorde. 1997. Pollen as foodstuff. Economic Botany 51(1):78-86.

Long, J., A. Tecle \& B. Burnette. 2003. Cultural foundations for ecological restoration on the White Mountain Apache Reservation. Ecology and Society 8(1):4. www. ecologyandsociety.org/vol8/iss1/art4/.

Ludwin, R.S., C.P. Thrush, K. James, D. Buerge, C. Jonientz-Trisler, J. Rasmussen, K. Troost \& A. de los Angeles. 2005. Serpent spirit-power stories along the Seattle Fault. Seismological Research Letters 76(4):426-431.

Malten, T. 2003. Sanskrit, Tamil and Pahlavi Dictionaries (from Cologne Digital Sanskrit Lexicon). webapps.unikoeln.de/tamil/.

Manataka Indian Council. 2007. Plants. www.manataka. org.

Marles, R.J., C. Clavelle, L. Monteleone, N. Tays \& D. Burns. 2000. Aboriginial Plant Use in Canada's Northwest Boreal Forest. University of British Columbia Press, Vancouver, Canada.

Marquand, E.C. 1938. Plant symbolism in the unicorn tapestries. Parnassus 10(5):2-8, 33, 40.

Martínez, M. 1979. Católogo de nombres vulgares y científicas de plantas mexicanas. Fondo de Cultura Económica, Mexico.

Masthay, C. 2003. The Piasaw. www.ani-kutani.com/piasaw.htm.
Mathews, P. \& P. Bíró. 2006. Maya Hieroglyph Dictionary. research.famsi.org/mdp/mdp_index.php.

Mathews, R.H. 1944. Chinese-English Dictionary (A Chinese-English Dictionary Compiled for the China Inland Mission). Harvard University Press, Cambridge, MA.

Matthews, W. 1885. Mythic dry-paintings of the Navajos. The American Naturalist 19(10):931-939.

Matthews, W. 1886. Navajo names for plants. The American Naturalist 20(9):767-777.

Matthews, W. 1888. The prayer of a Navajo shaman. American Anthropologist 1(2):148-171.

Matthews, W. 1902. The Night Chant, a Navajo Ceremony. Memoirs of the American Museum of Natural History Vol. 6. The Knickerbocker Press, New York.

Mayes, V.O. \& B. B. Lacy. 1989. Nanisé. A Navajo Herbal. Navajo Community College Press, Tsaile, AZ.

McNeil, C.L. 2007. Editor of Chocolate in Mesoamerica: A cultural history of cacao. University Press of Florida, Gainesville, FL.

Mekeel, H.S. 1935. Subsistance plant foods and preparation. Pp. 48-57 in Walapai Ethnography. Memoirs of the American Anthropological Association No. 42. Edited by F.B. Kniffen, G. McGregor, R.A. McKennan, H.S. Mekeel, M. Mook, \& A.L. Kroeber. Menasha, WI.

Méteaux, A. 1946. Myths of the Toba and Pilagá Indians of the Gran Chaco. Memoirs of the American Folkloric Society, Vol. 40. Philadelphia, PA.

Meyer, B.H. \& A.W. Glover. 1989. Botany and art in Leonardo's "Leda and the Swan." Leonardo 22(1):75-82.

Michelson, T. 1935. Phonetic shifts in Algonquian language. International Journal of American Linguistics 8(3/4):131-171.

Mitich, L.M. 2000. Common cattail, Typha latifolia L. Weed Technology 14(2):446-450.

Monier-Williams, M. 1899. A Sanskrit-English dictionary etymologically and philologically arranged with special reference to cognate Indo-European languages. The Clarendon Press, Oxford.

Mora-Morín, D.F. 2003. The origin of Mayan syllabograms and orthographic conventions. Written Language \& Literacy 6(2):193-238. 
Morgan, W.T.W. 1981. Ethnobotany of the Turkana: Use of plants by a pastoral people and their livestock in Kenya. Economic Botany 35:96-130.

Mors, W.B., C.T. Rizzini \& N.A. Pereira. 2000. Editors of Medicinal Plants of Brazil. Reference Publications, Inc., Algonac, MI.

Morton, J.F. 1975. Cat-tails (Typha spp.): Weed problems or potential crop? Economic Botany 29:7-29.

Mossberg, B. \& L. Stenberg. 1994. Gyldendals Store Nordiske Flora. Gyldendal Norsk Forlag, Oslo, Norway.

Mundkur, B. 1984. The bicephalous "animal style" in northern Eurasian religious art and its western hemisphere analogues. Current Anthropologist 25(4):451-482.

Munro, P. \& C. Willmond. 1994. Chickasaw: An analytical dictionary. University of Oklahoma Press, Norman, OK.

Munro, P., N. Brown, \& J. G. Crawford. 1992. A Mojave dictionary. UCLA Occasional Papers in Linguistics No. 10. Department of Linguistics, University of California, Los Angeles, CA.

Murison, R.G. 1905. The serpent in the Old Testament. The American Journal of Semitic Languages and Literatures 21(2):115-130.

Murphey, E.V.A. 1958. Indian Uses of Native Plants. Reprinted 1990 by Meyerhooks Publications, Glenwood, IL.

Nabhan, G.P. 1983. Papago Fields: Arid lands ethnobotany and agricultural ecology. Ph.D. Dissertation. University of Arizona, Tucson.

Nayar, T.S., A. Prasiya Beegam, N. Monhanan, G. Rajkumar \& M. Sibi. 2006. Flowering Plants of Kerala - A handbook. Tropical Botanic Garden and Research Institute, India.

O'Bryan, A. 1956. The Diné: Origin myths of the Navaho Indians. Bulletin 163 of the Bureau of American Ethnology. Smithsonian Institution, Washington, DC.

OED Online. 2006. Oxford University Press. www.oed. com.

Ostapkowicz, J.D., D. Lepofsky, R. Shulting \& A. McHalsie. 2001. The use of cattail (Typha latifolia L.) down as a sacred substance by the Interior and Coast Salish. Journal of Ethnobiology 21(2):77-90.

Outer, R.W. den. 2001. Vernacular names of Surinam woody plants. Wageningen University, The Netherlands. library.wur.nl/way/catalogue/documents/vernacular_ names.pdf
Parrotta, J.A. 2001. Healing Plants of Peninsular India. CABI Publishing, New York, NY.

Parsons, E.C. 1924. Tewa kin, clan, and moiety. American Anthropologist, New Series 26(3):333-339.

Parsons, E.C. 1926a. Tewa Tales. Reprinted 1992, University of Arizona Press, Tucson.

Parsons, E.C. 1926b. The ceremonial calendar of the Tewa of Arizona. American Anthropologist, New Series 28(1):209-229.

Peng, C.-I. 2000. Editor of Revised Draft of Index to Codes of Vascular Plants of Taiwan. Taipei, Taiwan, Academia Sinica. hast.sinica.edu.tw/CO-2002-01-14.xls

Pittier, H. 1957. Ensayo sobre Plantas Usuales de Costa Rica. Universidad de Costa Rica, Serie Ciencias Naturales No. 2, San Jose, Costa Rica.

Porcher, M.H. 1995-2004. Searchable World Wide Web Multilingual Multiscript Plant Name Database. www.plantnames.unimelb.edu.au/Sorting/Frontpage.html

Pokorny, J. 1959. Indogermanisches Etymologisches Wörterbuch. Francke, Bern.

Proulx, P. 1984. Proto-Algic I: Phonological sketch. International Journal of American Linguistics 50(2):165-207.

Rand, S.T. 1888. Dictionary of the languages of the Micmac Indians, who reside in Nova Scotia, New Brunswick, Prince Edward Island, Cape Breton and Newfoundland. Nova Scotia Printing Co., Halifax, N.S.

Rands, R.L. 1954. Horned serpent stories. The Journal of American Folklore 67(263):79-81.

Rea, A.M. 1997. At the Desert's Green Edge. An Ethnobotany of the Gila River Pima. The University of Arizona Press, Tucson, AZ.

Read, W.A. 1938. Ten Alabama Place-Names. American Speech 13(1):79-80.

Robbins, W.W., J.P. Harrington \& B. Freire-Marreco. 1916. Ethnobotany of the Tewa Indians. Smithsonian Institution Bureau of American Ethnology Bulletin 55. Smithsonian Institution Press, Washington.

Rollings, W.H. 1995. The Osage: An ethnohistorical study of hegemony on the Prairie-Plains. University of Missouri Press, Columbia.

Rubatt, A. 2006. Dizionario Universale della Lingua di Sardegna. www.toninorubattu.it/ita/T-1(ta-to).htm. 


\section{Austin - Sacred Connections with Cat-tail (Typha, Typhaceae) - Dragons, water-serpents and reed-maces}

Rudes, B.A. 1999. Tuscarora-English/English-Tuscarora Dictionary. University of Toronto Press, Toronto.

Ruhlen, M. 1998. The origin of the Na-Dene. Proceedings of the National Academy of Sciences 95(23):1399413996.

Russell, F. 1898. An Apache medicine dance. American Anthropologist 11(12):367-372.

Sachse, F. \& A.J. Christenson. 2005. Tulan and the Other Side of the Sea: Unraveling a metaphorical concept from Colonial Guatemalan Highland sources. www.mesoweb. com/articles/tulan/tulan.pdf.

Saha, S. 1968. The genus Typha in India - Its distribution and uses. Bulletin of the Botanical Society of Bengal 22:11-18.

Sanders, T.E. 1973. Tribal literature: Individual identity and the collective unconscious. College Composition and Communication 24(3):256-266.

Sapir, E. 1907. Religious ideas of the Takelma Indians of southwestern Oregon. The Journal of American Folklore 20(76):33-49.

Sapir, E. 1930. The Southern Paiute language. Proceedings of the American Academy of Arts and Sciences 65:1730. Reprinted 1990, AMS Press, New York, N.Y.

Saxton, D. \& L. Saxton. 1973. O'odham Hoho'ok A'agitha. Legends and Lore of the Papago and Pima Indians. University of Arizona Press, Tucson.

Scott, M. 1995. Scottish Wild Flowers. HarperCollins Publishers, London.

Shaul, D.L. 2007. Dictionary of O'odham. Unpublished mss.

Shaul, D.L. \& J.H. Hill. 1998. Tepimans, Yumans, and other Hohokam. American Antiquity 63(3):357-396.

Siméon, R. 1885. Diccionario de la Lengua Náhuatl o Mexicana. Reprinted 1981, Siglo Veintiuno Editores, S.A., Mexico City.

Smith, G.F. 1993. Familial orthography: Aloeaceae vs. Aloaceae. Taxon 42(1):87-90.

Smith, L.M. 1998. Navajo: Dine (The People). www.ausbcomp.com/redman/ navajo.htm.

Smith, N.P., S.A. Mori, A. Anderson, D.W. Stevenson \& S.V. Heald. 2004. Editors of Flowering Plants of the Neotropics. New York Botanical Garden and Princeton University Press, Princeton, NJ.
Smith, P. 1994. Editor of Favorite North American Indian Legends. Courier Dover Publications, NY. Speck, F.W. 1935. Penobscot tales and religious beliefs. The Journal of American Folklore 48(187):1-107.

Spier, L. 1933. Yuman Tribes of the Gila River. University of Chicago Press, Chicago, IL.

Stevenson, M.C. 1915. Ethnobotany of the Zuñi Indians. Thirtieth Annual report of the Bureau of American Ethnology to the Secretary of the Smithsonian Institution, 19081909. Washington, DC. Reprinted 1993, as The Zuni Indians and Their Uses of Plants. Dover Publishing Co., New York.

Steward, J. 1960. Review of The Origin of Civilized Societies, by Rushton Coulborn. American Anthropologist, New Series 62(1):153-155.

Stirling, M.W. 1942. Origin myth of Acoma and other Records. Bureau of American Ethnology Bulletin 135. Smithsonian Institution, Washington, DC.

Sturtevant, W.C. 1955. The Mikasuki Seminole: Medical beliefs and practices. Ph.D. Dissertation, Department of Anthropology, Yale University. University Microfilms, Inc., Ann Arbor, Michigan.

Swank, G.R. 1932 The Ethnobotany of the Acoma and Laguna Indians. M.A. Thesis, University of New Mexico.

Swanton, J.R. 1928. Chickasaw society and religion. Forty-second Annual report of the U.S. Bureau of American Ethnology. Reprinted with foreword by G. O'Brien. 2006. University of Nebraska Press, Lincoln.

Taylor, A. 1947. Ainu riddles. Western Folklore 6(2):163173.

Thieret, J.W. \& J.O. Luken. 1996. The Typhaceae of the Southeastern United States. Harvard Papers in Botany $8: 27-56$

Timbrook, J. 1990. Ethnobotany of the Chumash Indians, California, based on collections by John P. Harrington. Economic Botany 44:236-253.

Turner, N.J. 1998. Plant Technology of First Peoples in British Columbia. UBC Press, University of British Columbia, Vancouver, Canada.

Turner, N.J. \& M.A.M. Bell. 1971. The ethnobotany of the Coast Salish Indians of Vancouver Island. Economic Botany 25:63-104, Appendix 335-339.

Turner, N.J. \& M.A.M. Bell. 1973. The ethnobotany of the southern Kwakiutl Indians of British Columbia. Economic Botany 27:257-310. 
uBio. 2004. Universal Biological Indexer and Organizer. The Marine Biological Laboratory, Woods Hole, MA. www. ubio.org/.

Uhlenbeck, C.C. 1924. Some word-comparisons between Blackfoot and other Algonquian languages. International Journal of American Linguistics 3(1):103-108.

Vest, E.B. 1948. Native words learned by American soldiers in India and Burma in World War II. American Speech 23(3/4):223-231.

Vestal, P.A. 1952. Ethnobotany of the Ramah Navaho. Papers of the Peabody Museum of American Archaeology and Ethnology 40(4):1-94.

Voegelin, C.F. 1956. Phonemicizing for dialect study, with reference to Hopi. Language 32(1):116-135.

Walcot, P. 1956. The text of Hesiod's Theogony and the Hittite Epic of Kumarbi. The Classical Quarterly, New Series 6(3/4):198-206.

Walker, E.H. 1976. Flora of Okinawa and the Southern Ryukyu Islands. Smithsonian Institution Press, Washington, DC.

Ward, D.B. 2007. Keys to the Flora of Florida - 15, Typha (Typhaceae). Phytologia 89(1):58-65.

Watahomigie, L.J., M. Powskey, J. Bender, E. Matapais, \& F. Hunt. 1982. Hualapai Ethnobotany. Hualapai Bilingual Program, Peach Springs School Distict No. 8, Peach Springs, AZ.

Watt, G. 1889. A Dictionary of the Economic Products of India. Reprinted 1972, Bishen Singh Mahendra Pal Singh, Dehra Dun, India.

White, R.C. 2003. Elsevier's Dictionary of Plant Names of North America Including Mexico. Elsevier B.V., Amsterdam, The Netherlands.

Whiting, A.E. 1939. Ethnobotany of the Hopi. Reprinted 1966, Northland Press, Flagstaff. Originally published in Museum of Northern Arizona Bulletin 15, Flagstaff.

Wikipedia. 2007. Wikipedia, the Free Encyclopedia. en.wikipedia.org/.

Wilcox, D.R. 1981. The Entry of Athapaskans into the American Southwest: The problem today. Pp. 213-256 in The Protohistoric Period in the North American South- west, A.D. 1450-1700. Anthropological Research Papers No. 24. Edited by D.R. Wilcox \& W.B. Masse. Arizona State University, Tempe.

Wilson, J.A.P. 2005. Relatives halfway around the world: Southern Athabascans and Southern Tarim fugitives. Limina 11:67-78.

Wright, B. 1988. The Mythic World of the Zuni as Written by Frank Hamilton Cushing. Edited and illustrated by Barton Wright. University of New Mexico Press, Albuquerque.

Wyman, L.C. 1936a. The female shooting life chant: A minor Navaho ceremony. American Anthropologist, New Series 38(4):634-653.

Wyman, L.C. 1936b. Navaho diagnosticians. American Anthropologist New Series 38(2):236-246.

Wyman, L.C. \& C. Kluckhorn. 1938. Navajo classification of their song ceremonials. American Anthropological Association Memoirs No. 50. Menasha, WI.

Wyman, L.C. \& S.K. Harris. 1941. Navajo Indian Medical Ethnobotany. The University of New Mexico Bulletin No. 366, Anthropological Series 3(5):1-75. Albuquerque, New Mexico.

Wyman, L.C. \& F.L. Bailey. 1945. Idea and action patterns in Navaho Flintway. Southwestern Journal of Anthropology 1(3):356-377.

Wyman, L.C. \& F.L. Bailey. 1946. Navajo Striped Windway, an Injury-way chant. Southwestern Journal of Anthropology 2(2):213-238.

Yetman, D. \& Van Devender, T.R. 2002. Mayo Ethnobotany. Land, History, and Traditional Knowledge in Northwest Mexico. University of California Press, Berkeley, CA.

Young, R.W. \& Morgan, W. 1980. The Navajo Language. A Grammar and Colloquial Dictionary. University of New Mexico Press, Albquerque, NM.

Yung, N. and N. Yao. 1985. Species List of Vascular Plants of Taiwan. The Experimental Forest, National Taiwan University, Taipei, Taiwan.

Zohary, M. 1982. Plants of the Bible. Cambridge University Press, Cambridge. 

water-serpents and reed-maces

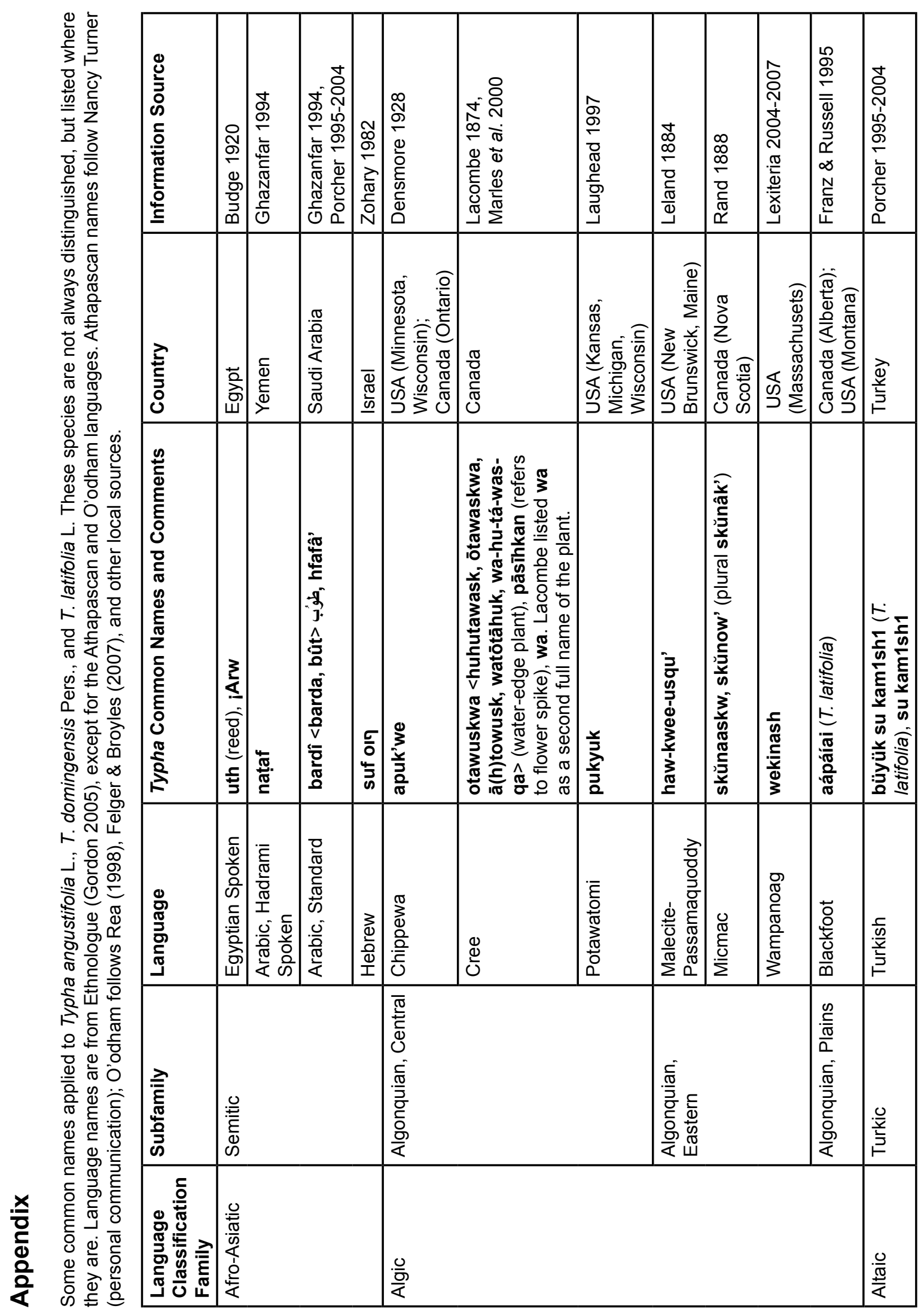




\begin{tabular}{|c|c|c|c|c|c|c|c|c|c|c|c|c|c|c|c|c|c|}
\hline 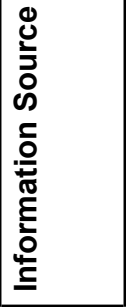 & 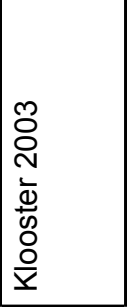 & 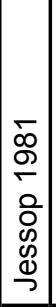 & 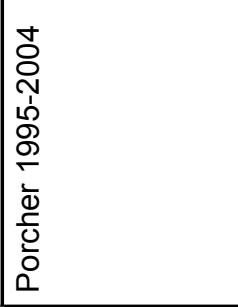 & 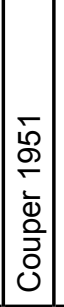 & 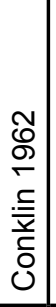 & 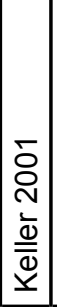 & 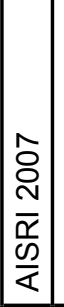 & 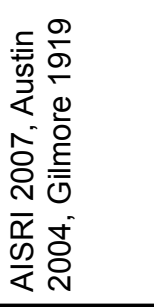 & 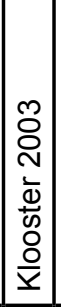 & 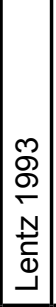 & 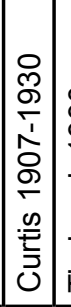 & 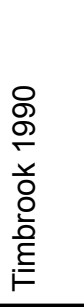 & 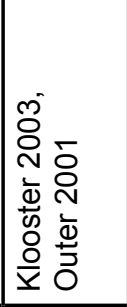 & 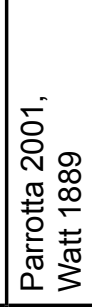 & 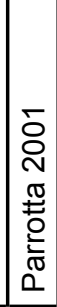 & 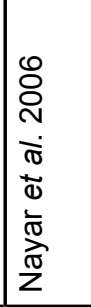 & 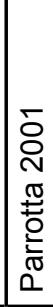 \\
\hline 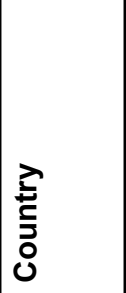 & 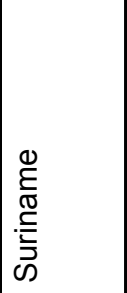 & 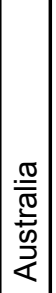 & 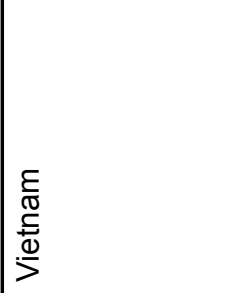 & 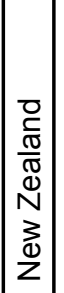 & 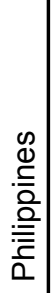 & $\mid \frac{\pi}{\geq}$ & 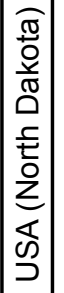 & 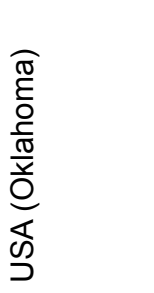 & 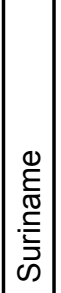 & 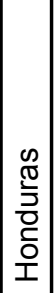 & 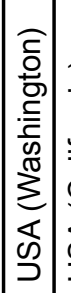 & 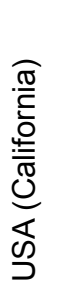 & 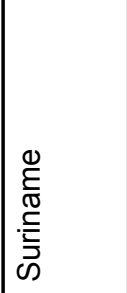 & $\begin{array}{l}\underline{\underline{0}} \\
\underline{\underline{\Xi}}\end{array}$ & $\begin{array}{l}\underline{\underline{\sigma}} \\
\underline{\underline{\underline{O}}}\end{array}$ & $\begin{array}{l}\frac{\underline{\sigma}}{0} \\
\underline{\underline{5}}\end{array}$ & 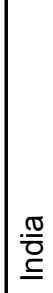 \\
\hline 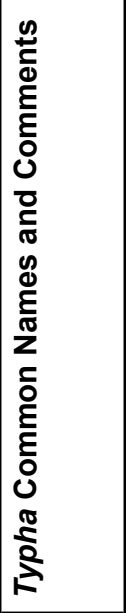 & 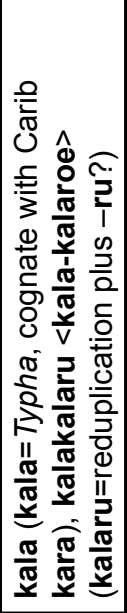 & 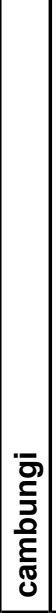 & 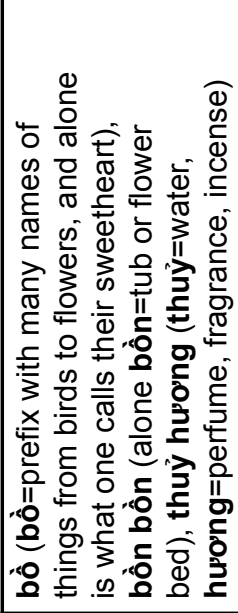 & \begin{tabular}{|l} 
\\
\\
$\circ$ \\
$\frac{2}{2}$ \\
$\frac{\pi}{2}$
\end{tabular} & $\begin{array}{l}\text { ते } \\
\frac{\pi}{\pi} \\
\frac{0}{2} \\
\frac{\sigma}{\pi} \\
\frac{\pi}{2}\end{array}$ & 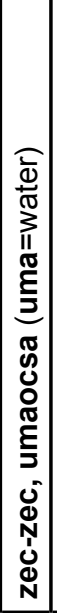 & $\frac{.0}{\varepsilon}$ & 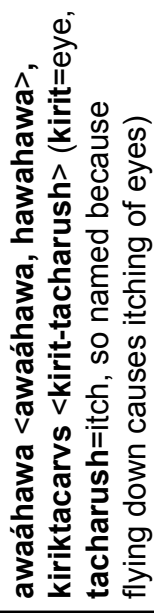 & 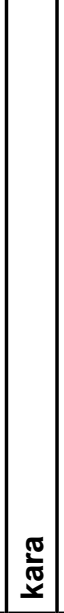 & 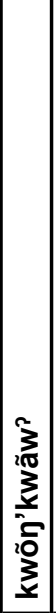 & 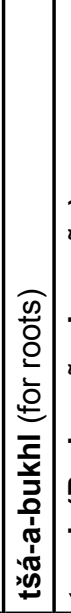 & 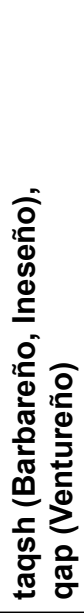 & 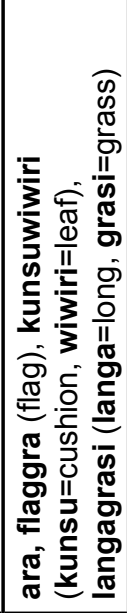 & 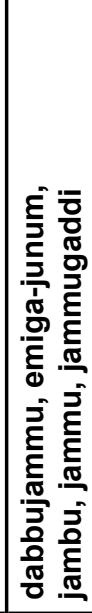 & 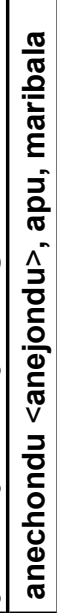 & 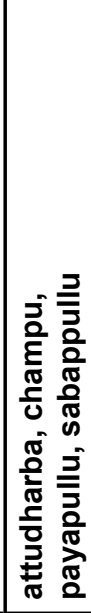 & 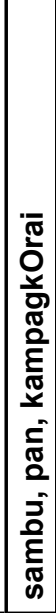 \\
\hline 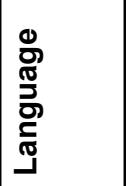 & 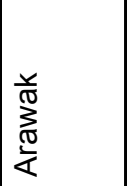 & 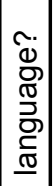 & 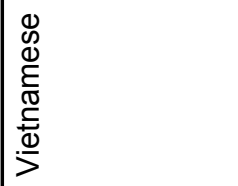 & 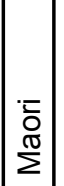 & 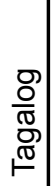 & 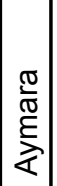 & 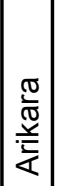 & 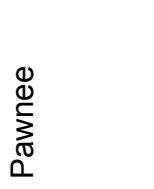 & 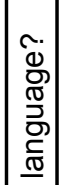 & $\mid \begin{array}{l}\overline{\mathcal{O}} \\
\mathrm{D} \\
0\end{array}$ & 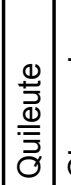 & $\begin{array}{l}\frac{1}{10} \\
\mathbb{D} \\
\frac{E}{5} \\
\frac{1}{U}\end{array}$ & $\begin{array}{l}\frac{c}{\sigma} \\
\frac{\pi}{\pi} \\
\frac{\pi}{\omega} \\
\omega\end{array}$ & $\frac{\vec{\partial}}{\frac{\vec{D}}{\omega}}$ & 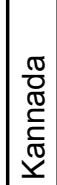 & 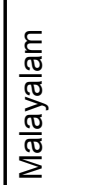 & \begin{tabular}{|l}
$\overline{\overline{\bar{\varepsilon}}}$ \\
$\stackrel{\bar{\sigma}}{\sigma}$
\end{tabular} \\
\hline $\begin{array}{l}\frac{\lambda}{\bar{E}} \\
\frac{\pi}{\pi} \\
\frac{\pi}{\frac{\pi}{3}} \\
\dot{\omega}\end{array}$ & 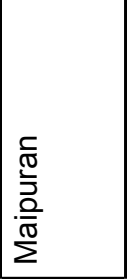 & 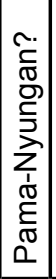 & 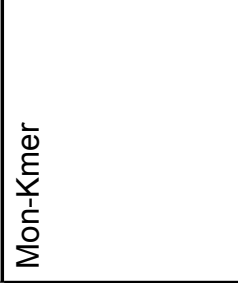 & 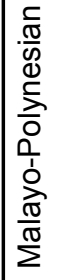 & & 1 & 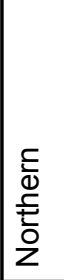 & & 1 & 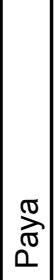 & 1 & 1 & 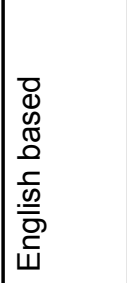 & 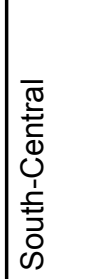 & 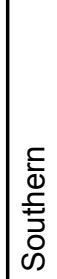 & & \\
\hline 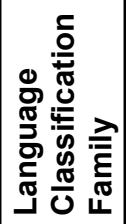 & 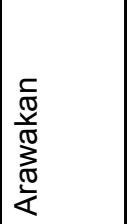 & 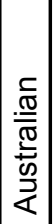 & 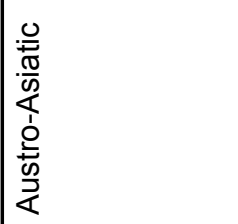 & 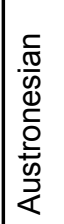 & & 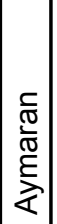 & 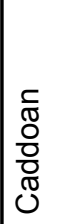 & & $\left|\begin{array}{l}\circ \\
\stackrel{2}{\bar{T}} \\
\mathcal{D}\end{array}\right|$ & $\mid$\begin{tabular}{l|}
$\frac{c}{0}$ \\
$\frac{0}{0}$ \\
$\frac{0}{7}$ \\
$\frac{7}{0}$
\end{tabular} & 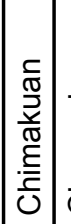 & $\begin{array}{l}\frac{1}{\mathcal{D}} \\
\mathbb{0} \\
\frac{\mathfrak{E}}{5} \\
\frac{1}{0}\end{array}$ & \begin{tabular}{|l}
$\frac{0}{0}$ \\
$\frac{d}{U}$ \\
U.
\end{tabular} & 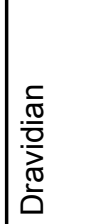 & & & \\
\hline
\end{tabular}


Austin - Sacred Connections with Cat-tail (Typha, Typhaceae) - Dragons, 293 water-serpents and reed-maces

\begin{tabular}{|c|c|c|c|c|c|c|c|c|c|c|c|c|}
\hline 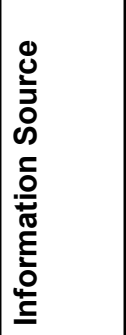 & 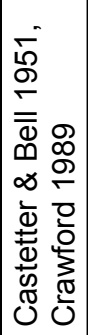 & 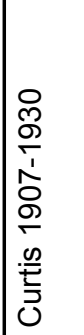 & 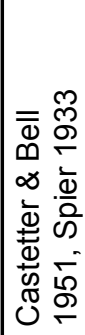 & 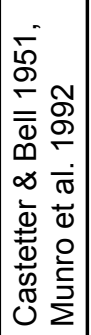 & 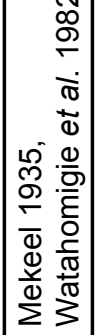 & 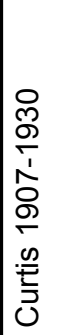 & 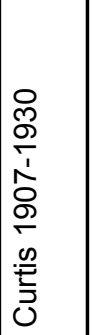 & 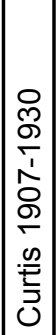 & 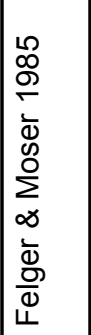 & 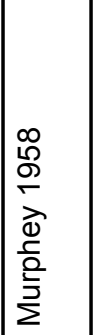 & 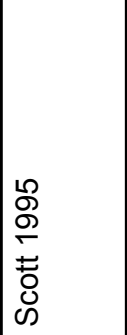 & 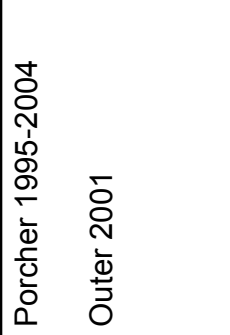 \\
\hline 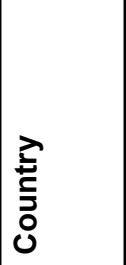 & 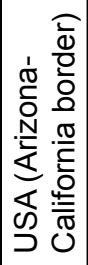 & 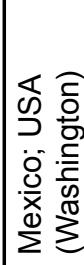 & 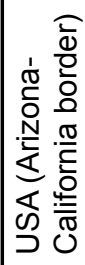 & 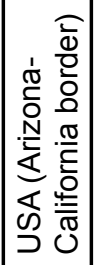 & 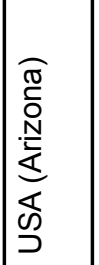 & 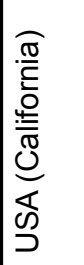 & 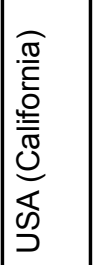 & 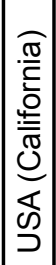 & 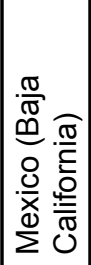 & 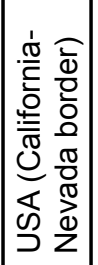 & $\begin{array}{l}\overline{0} \\
\frac{0}{\sigma} \\
\frac{\pi}{\pi} \\
\overline{0} \\
c \\
c\end{array}$ & 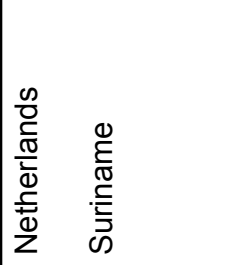 \\
\hline 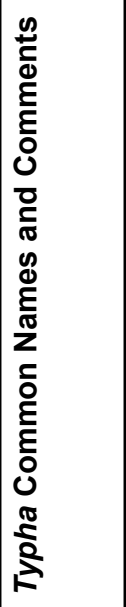 & 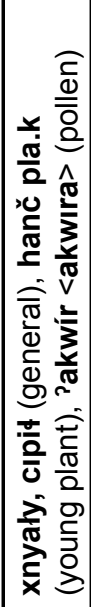 & 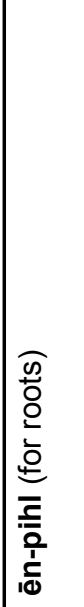 & 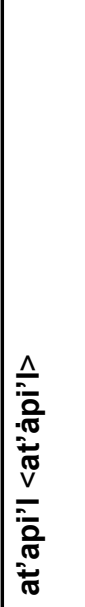 & 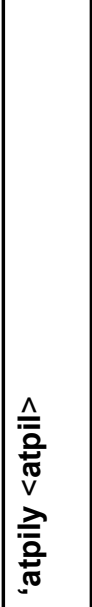 & 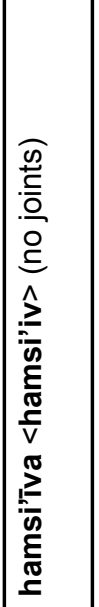 & 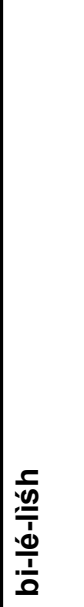 & 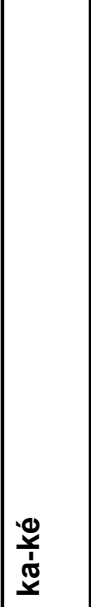 & $\overline{\widetilde{\Xi}}$ & \begin{tabular}{|l} 
苋 \\
|
\end{tabular} & 愛 & 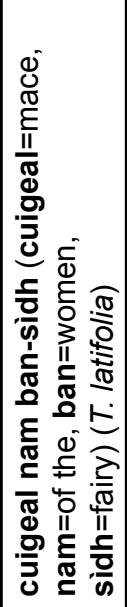 & 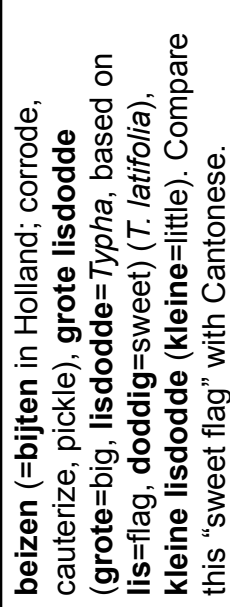 \\
\hline 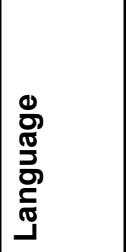 & $\begin{array}{l}\frac{\pi}{0} \\
\stackrel{0}{0} \\
0\end{array}$ & \begin{tabular}{|l}
$\frac{\cdot \overline{\underline{\pi}}}{\bar{E}}$ \\
$\underline{\underline{x}}$ \\
\end{tabular} & 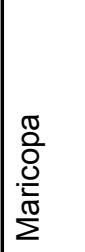 & 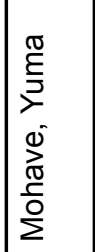 & $\begin{array}{l}\overline{\bar{\pi}} \\
\frac{\alpha}{\overline{0}} \\
\frac{\pi}{3}\end{array}$ & 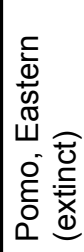 & 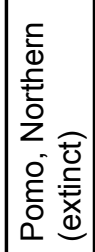 & 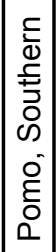 & $\begin{array}{l}\overline{\bar{D}} \\
\omega\end{array}$ & 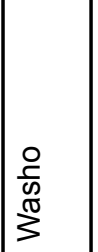 & 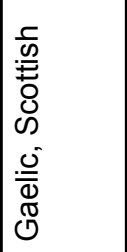 & 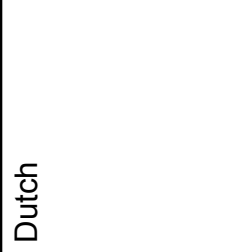 \\
\hline 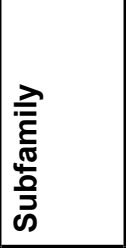 & 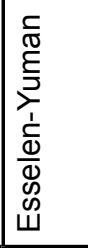 & & 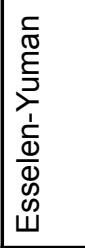 & & & 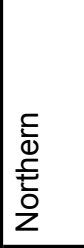 & & & 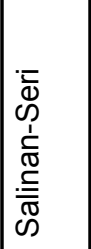 & $\begin{array}{l}\frac{0}{1} \\
\frac{1}{\mathscr{D}} \\
\stackrel{8}{3}\end{array}$ & 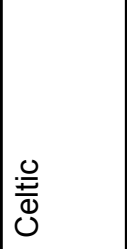 & 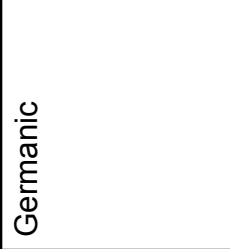 \\
\hline 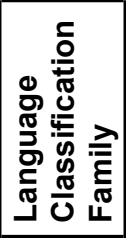 & 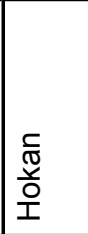 & & & & & & & & & & 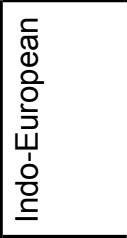 & \\
\hline
\end{tabular}




\begin{tabular}{|c|c|c|c|c|c|}
\hline 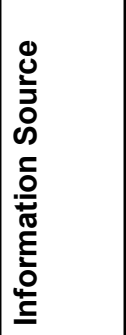 & 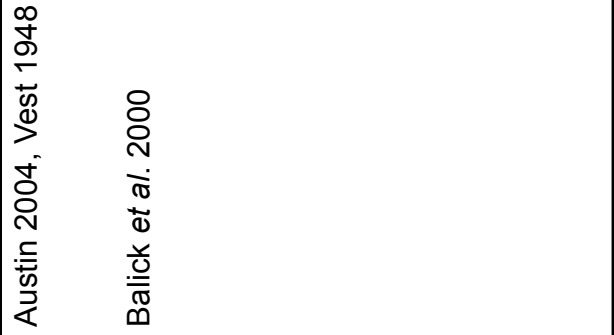 & 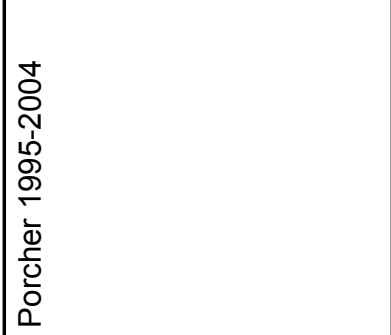 & 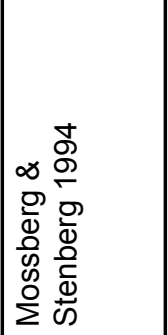 & 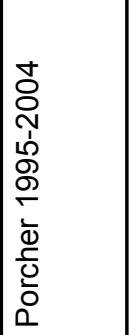 & 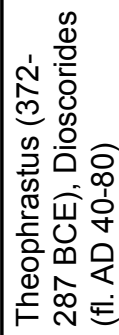 \\
\hline 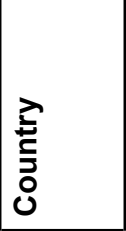 & 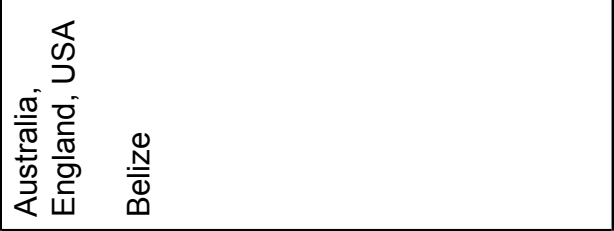 & 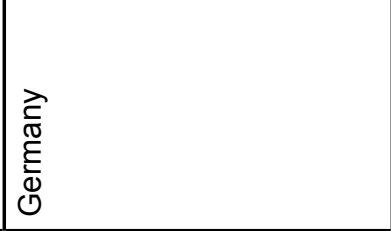 & \begin{tabular}{|l} 
ते \\
zo \\
z
\end{tabular} & $\begin{array}{l}\bar{c} \\
\overline{0} \\
0 \\
0 \\
0\end{array}$ & 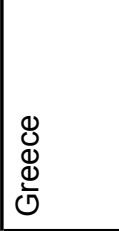 \\
\hline 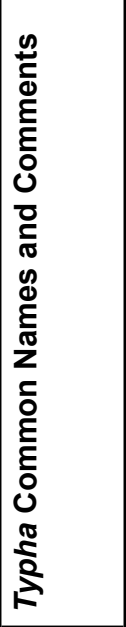 & 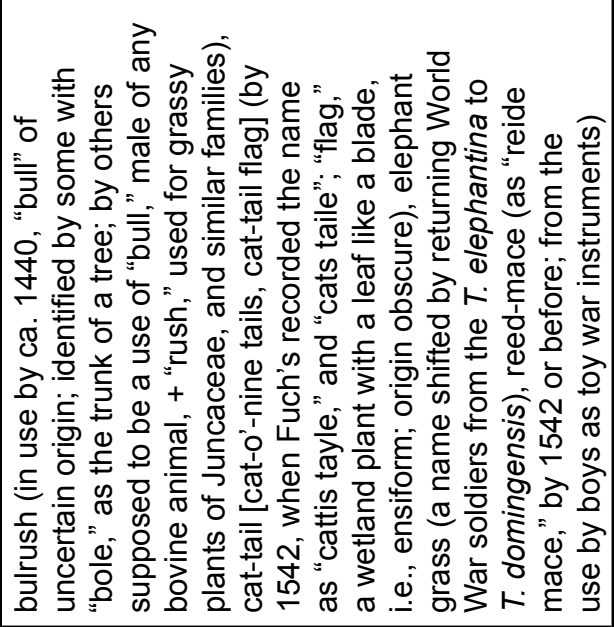 & 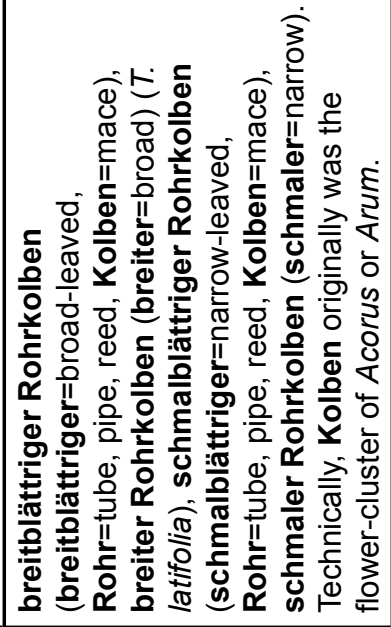 & 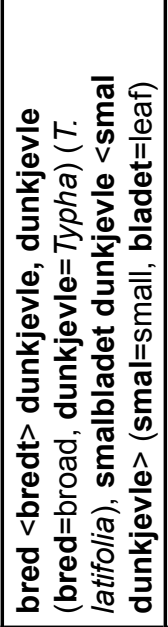 & 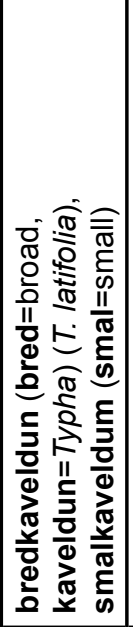 & 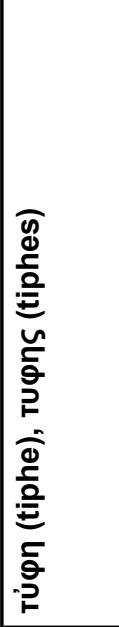 \\
\hline 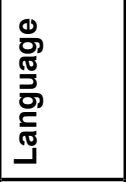 & 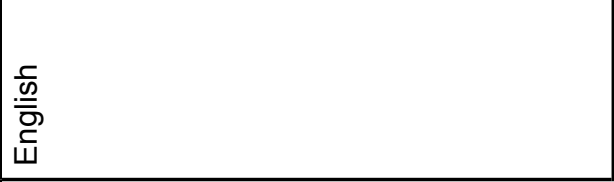 & 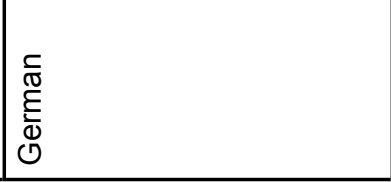 & 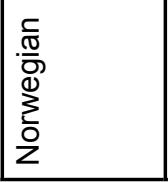 & 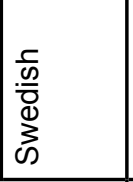 & \begin{tabular}{|l} 
\\
\\
$\stackrel{\nu}{0}$ \\
0
\end{tabular} \\
\hline 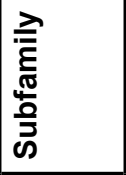 & 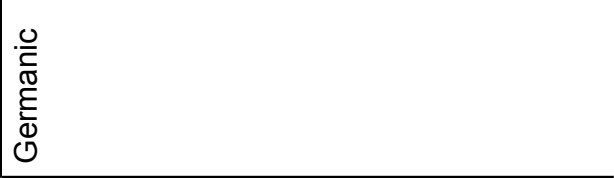 & & & & 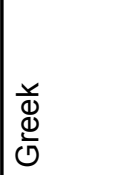 \\
\hline 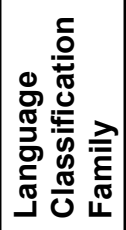 & 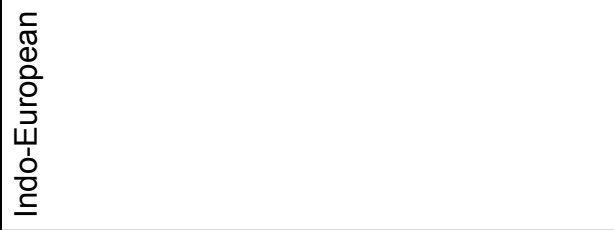 & & & & \\
\hline
\end{tabular}


Austin - Sacred Connections with Cat-tail (Typha, Typhaceae) - Dragons, water-serpents and reed-maces

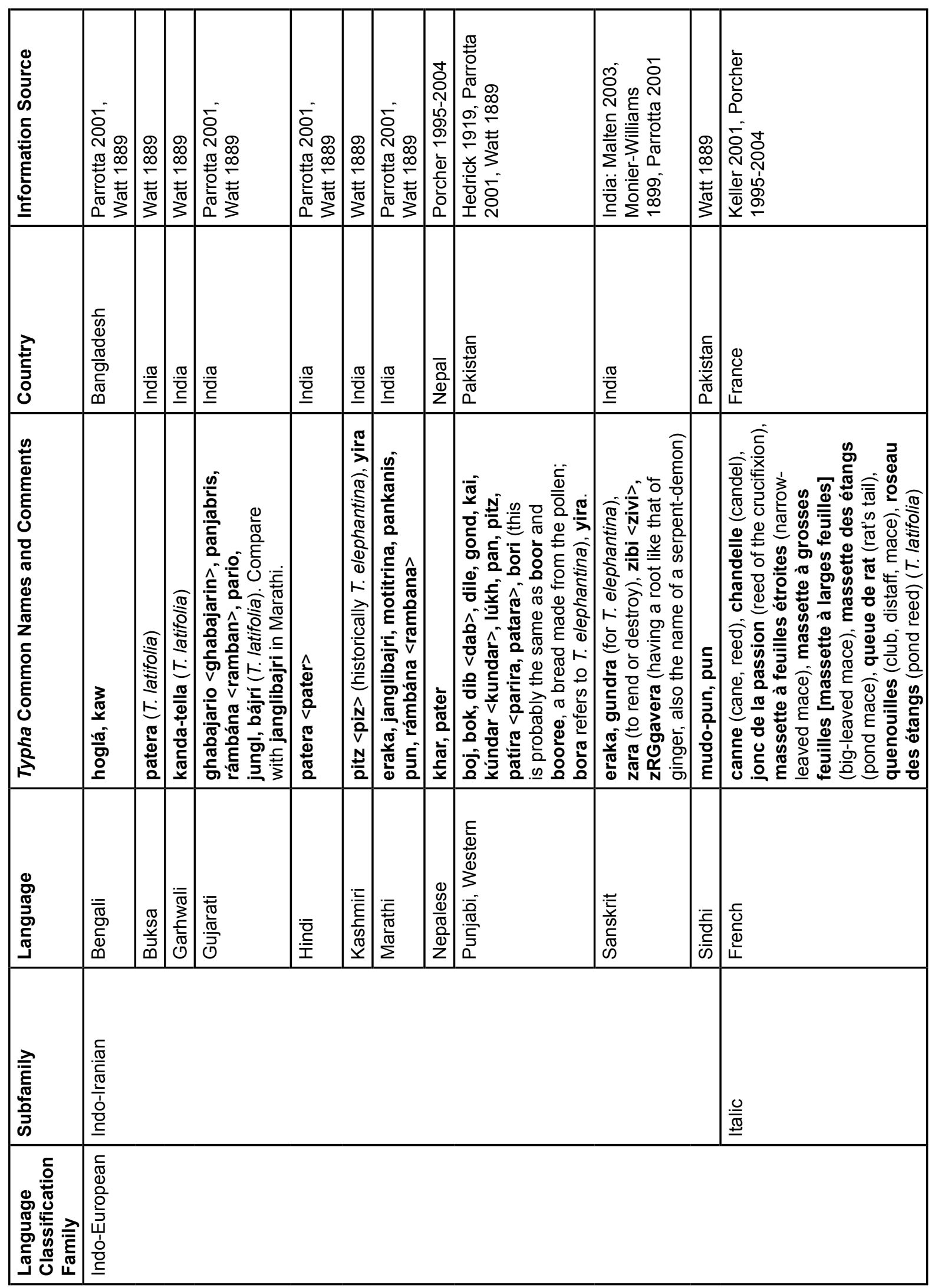




\begin{tabular}{|c|c|c|c|c|c|}
\hline 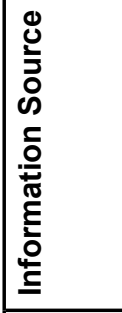 & 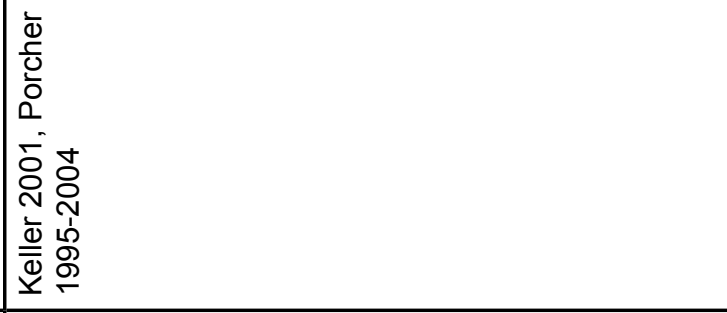 & 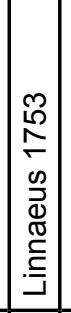 & 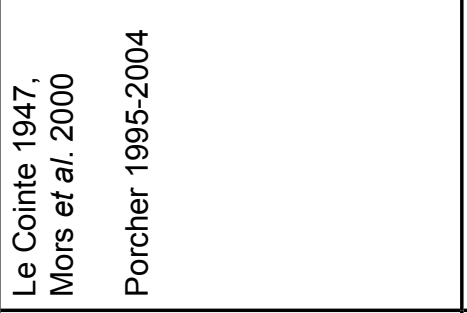 & 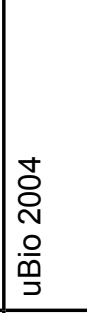 & 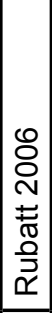 \\
\hline 全 & \begin{tabular}{|l} 
帝 \\
\end{tabular} & $\frac{\vec{\pi}}{\underline{\underline{\pi}}}$ & 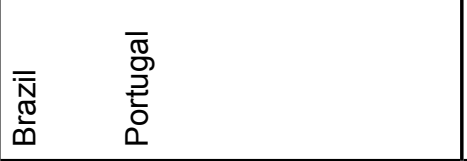 & 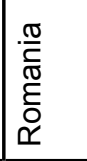 & 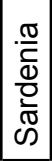 \\
\hline 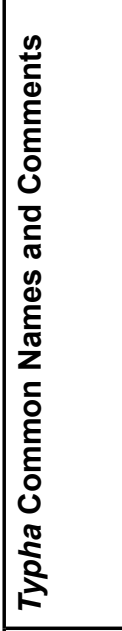 & 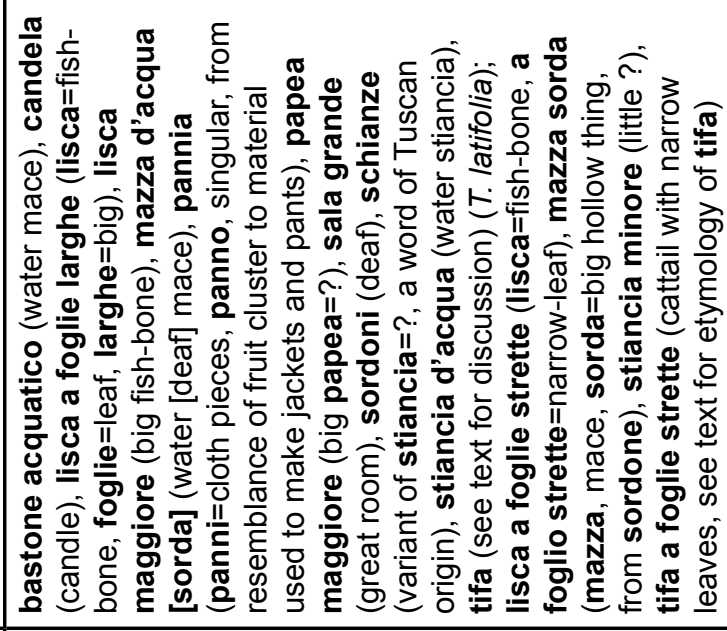 & & 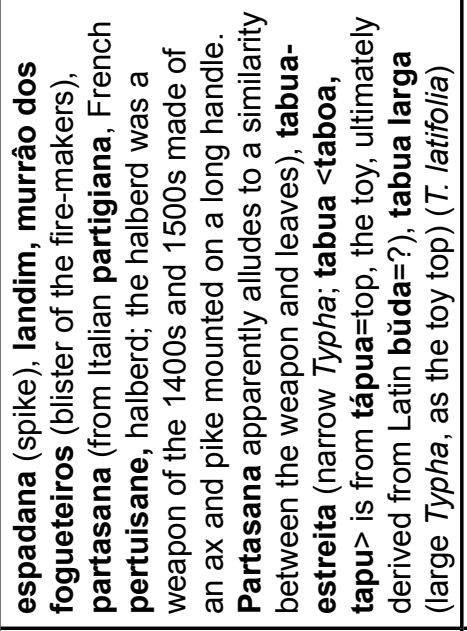 & 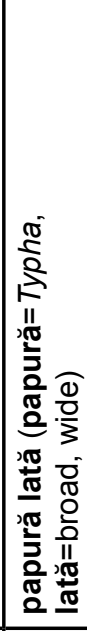 & 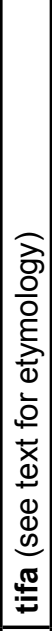 \\
\hline 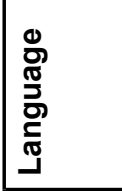 & \begin{tabular}{|l}
$\underline{\underline{\underline{w}}}$ \\
$\underline{\underline{\underline{w}}}$ \\
\end{tabular} & & 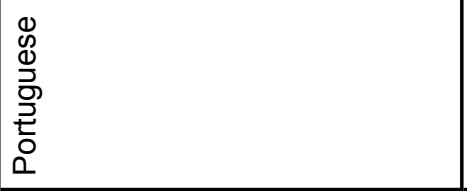 & 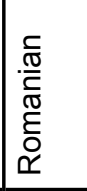 & 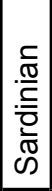 \\
\hline 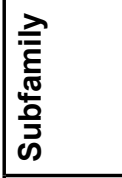 & 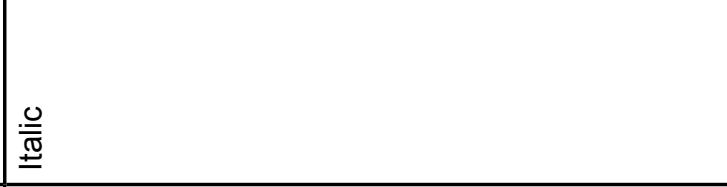 & & & & \\
\hline 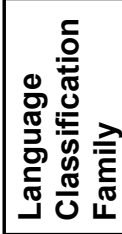 & 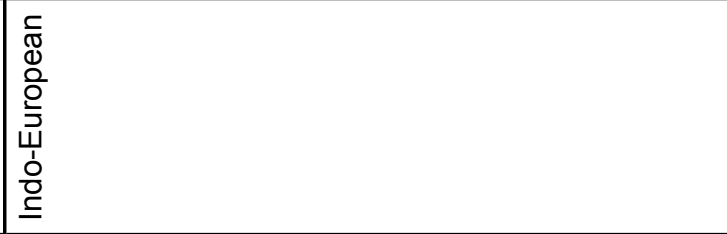 & & & & \\
\hline
\end{tabular}


Austin - Sacred Connections with Cat-tail (Typha, Typhaceae) - Dragons, 297 water-serpents and reed-maces

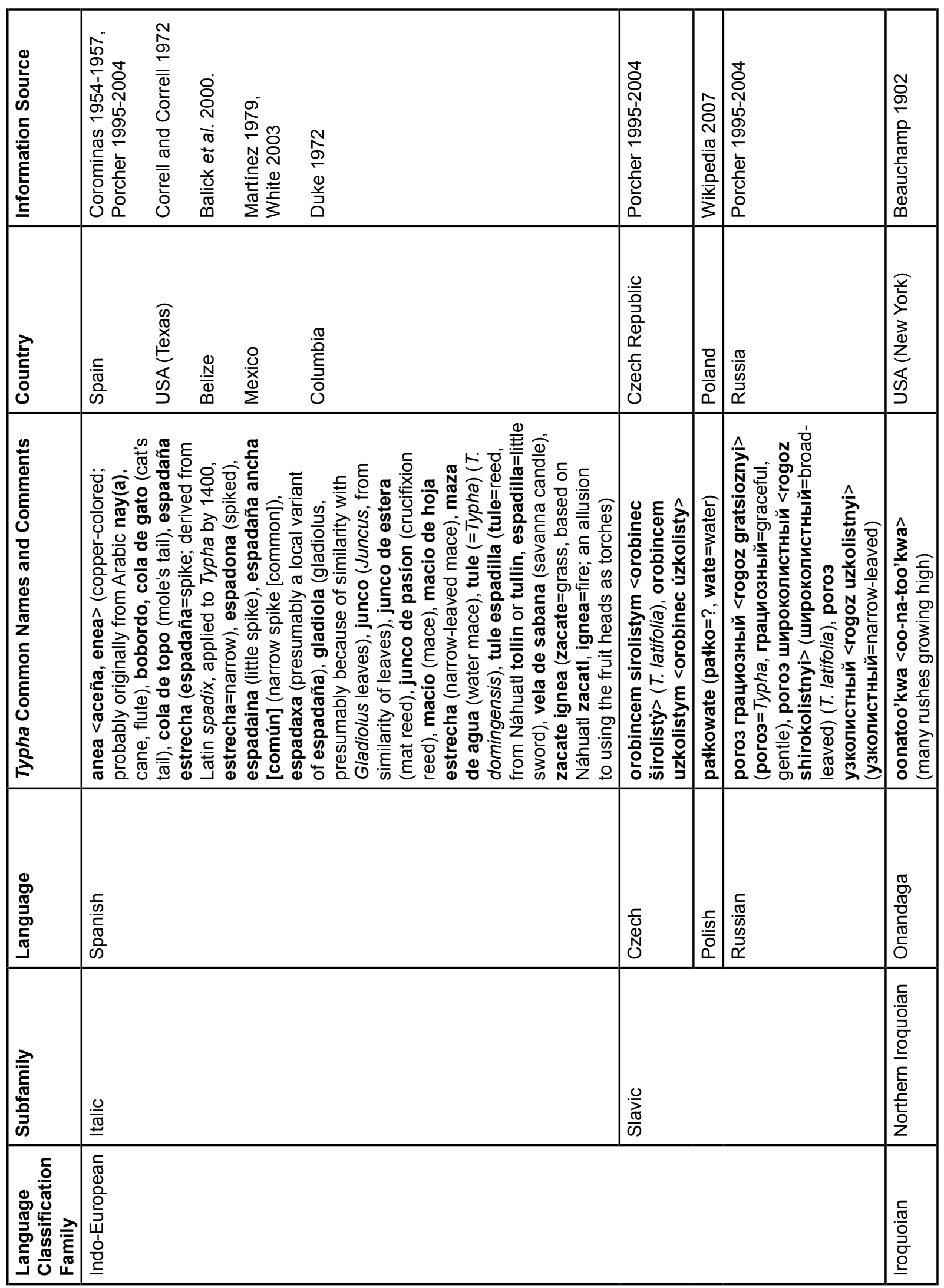




\begin{tabular}{|c|c|c|c|c|c|c|c|c|c|c|c|c|c|c|c|c|c|c|}
\hline 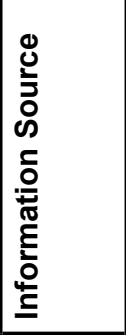 & 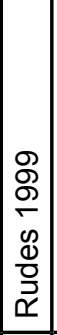 & 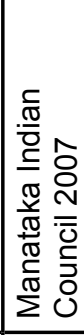 & 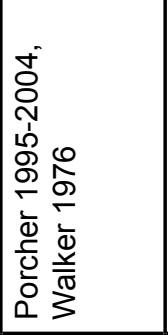 & 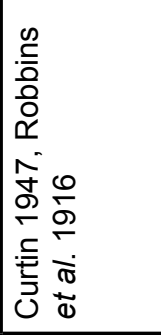 & $\begin{array}{l}\bar{\delta} \\
\bar{N} \\
\bar{\omega} \\
\overline{\bar{\omega}} \\
\underline{\underline{1}} \\
\end{array}$ & 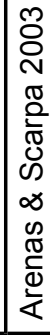 & 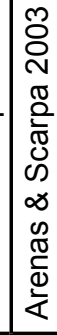 & 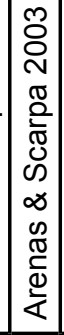 & 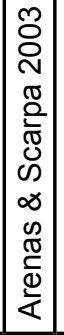 & 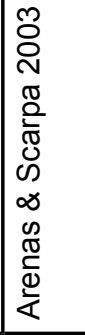 & 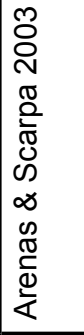 & 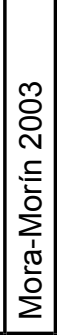 & 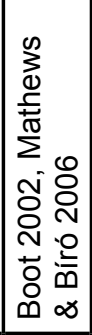 & 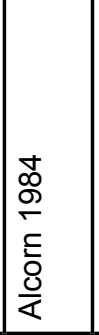 & 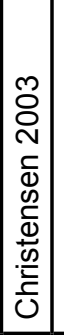 & 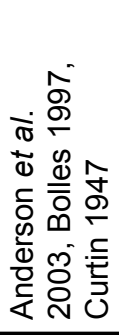 & 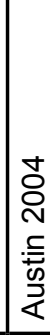 & 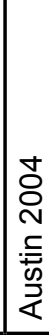 \\
\hline 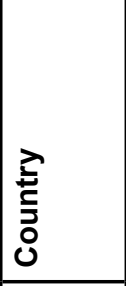 & 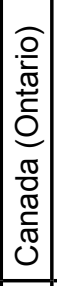 & 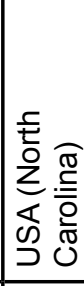 & 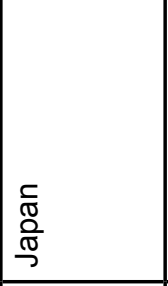 & 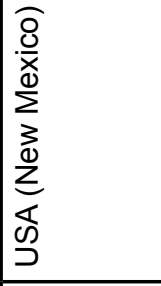 & $\begin{array}{l}: \frac{\pi}{2} \\
\overline{0} \\
0 \\
0\end{array}$ & $\begin{array}{l}\vec{\sigma} \\
\frac{\pi}{D} \\
\frac{\pi}{\sigma} \\
\frac{0}{\sigma} \\
0\end{array}$ & \begin{tabular}{|l}
$\frac{\widehat{\sigma}}{5}$ \\
$\frac{\pi}{0}$ \\
$\frac{\pi}{\sqrt{0}}$ \\
0
\end{tabular} & 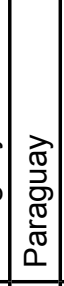 & 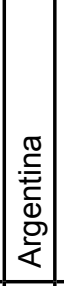 & 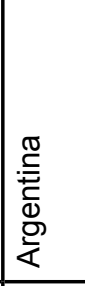 & 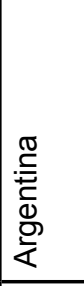 & 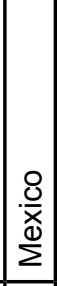 & 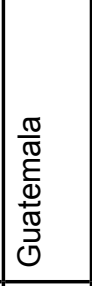 & 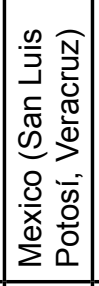 & 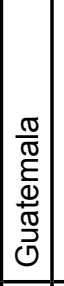 & $\begin{array}{l}0.0 \\
\frac{0}{x} \\
\sum^{0}\end{array}$ & 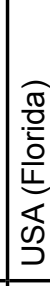 & $\begin{array}{l}\frac{\pi}{0} \\
\frac{0}{0} \\
\frac{0}{4} \\
\frac{5}{5} \\
د \\
\end{array}$ \\
\hline 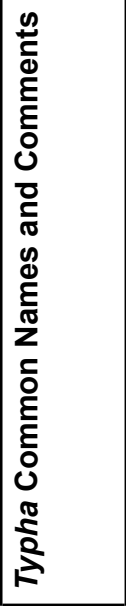 & 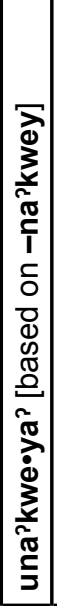 & 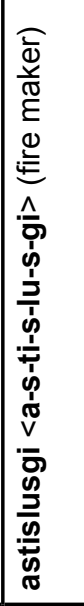 & 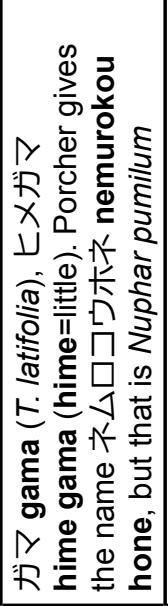 & 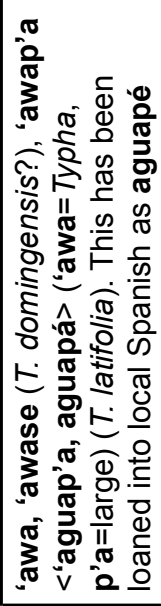 & 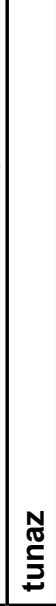 & $\mid \frac{8}{\frac{8}{\sigma}}$ & 豙 & 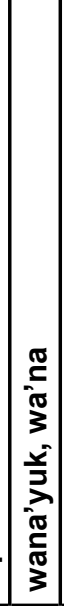 & 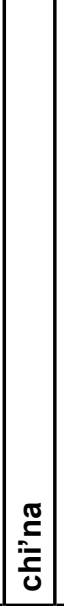 & 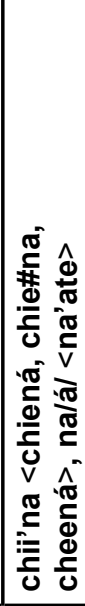 & 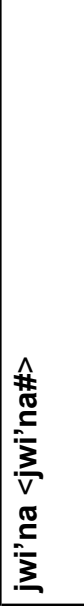 & 写 & 罙 & 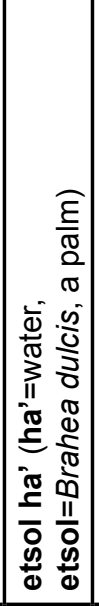 & 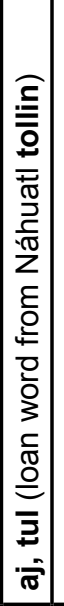 & 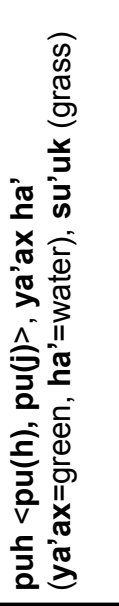 & 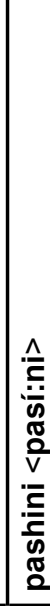 & 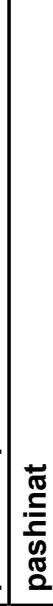 \\
\hline 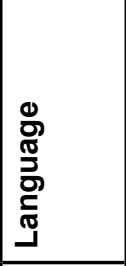 & 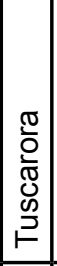 & 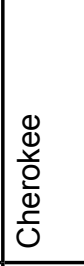 & 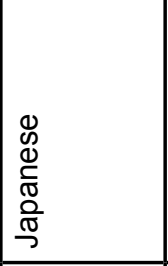 & 㿣 & 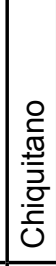 & \begin{tabular}{|l}
$\frac{\pi}{\sigma}$ \\
$\frac{\sigma}{\sigma}$ \\
$\stackrel{\Xi}{\sigma}$
\end{tabular} & 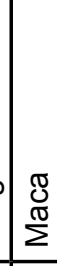 & $\left|\begin{array}{l}\frac{0}{0} \\
0 \\
\frac{\pi}{z} \\
\dot{z}\end{array}\right|$ & $\left|\begin{array}{l}\frac{\pi}{8} \\
\frac{\pi}{2} \\
\frac{\pi}{2}\end{array}\right|$ & $\begin{array}{l}0 \\
\stackrel{8}{0} \\
10\end{array}$ & 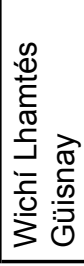 & \begin{tabular}{|}
$\overline{\bar{N}}$ \\
$\stackrel{0}{N}$ \\
$\stackrel{N}{N}$
\end{tabular} & $\begin{array}{l}\stackrel{\pi}{\pi} \\
\sum \\
\Sigma\end{array}$ & 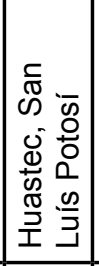 & 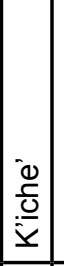 & 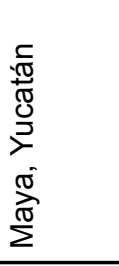 & 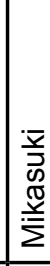 & 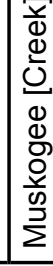 \\
\hline 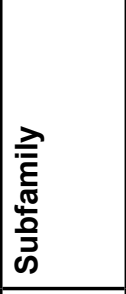 & 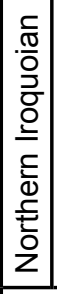 & 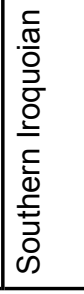 & $1 \mathrm{i}$ & 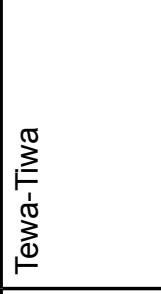 & 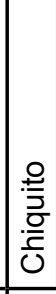 & $i$ & $\begin{array}{l}8 \\
\frac{0}{\pi} \\
\frac{\pi}{\pi} \\
\frac{\pi}{2}\end{array}$ & & & & & 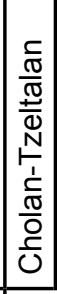 & 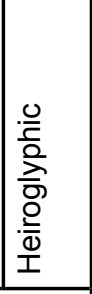 & 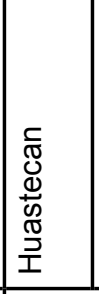 & 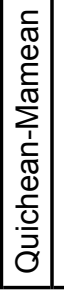 & 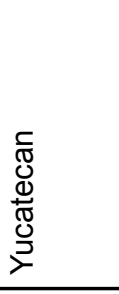 & & \\
\hline 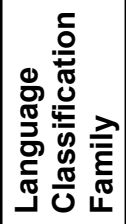 & 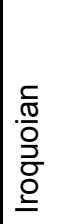 & & 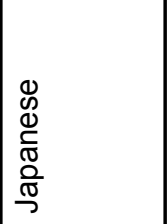 & 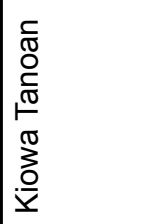 & \begin{tabular}{|l|}
0 \\
0 \\
1 \\
0 \\
0 \\
0 \\
$\Sigma$ \\
$\Sigma$
\end{tabular} & 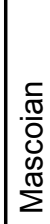 & $\Sigma$ & & & & & 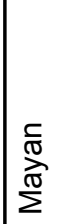 & & & & & $\begin{array}{l}\mathscr{8} \\
\stackrel{8}{2}\end{array}$ & \\
\hline
\end{tabular}


Austin - Sacred Connections with Cat-tail (Typha, Typhaceae) - Dragons, 299 water-serpents and reed-maces

\begin{tabular}{|c|c|c|c|c|c|c|c|c|c|c|c|c|c|}
\hline 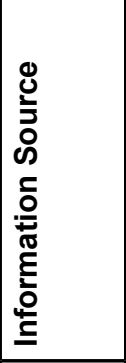 & 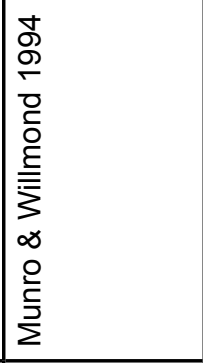 & 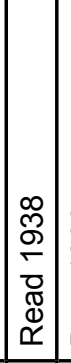 & 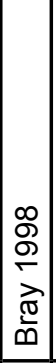 & 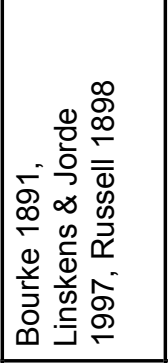 & 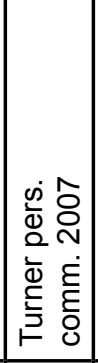 & 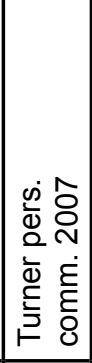 & 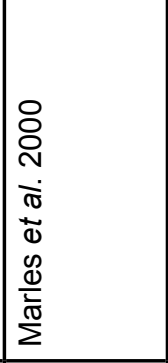 & 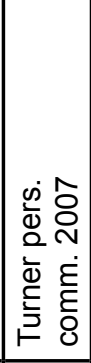 & 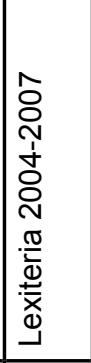 & 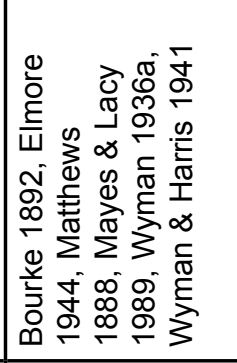 & 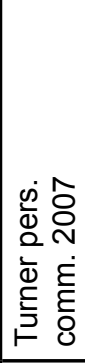 & 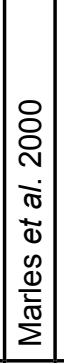 & 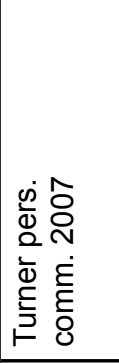 \\
\hline 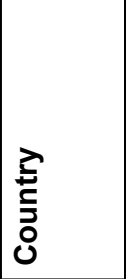 & 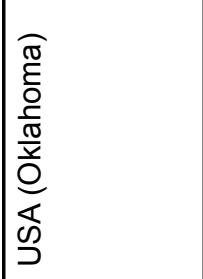 & 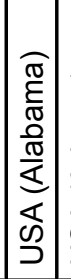 & 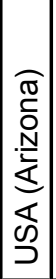 & 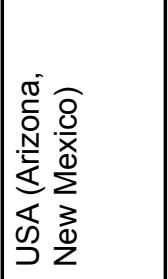 & 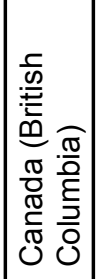 & 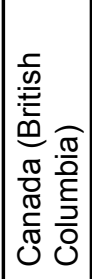 & \begin{tabular}{|l}
$\frac{\pi}{0}$ \\
$\tilde{D}$ \\
$\frac{0}{\pi}$ \\
0
\end{tabular} & 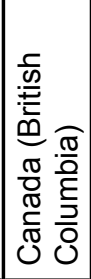 & 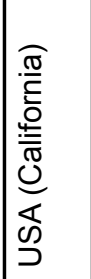 & 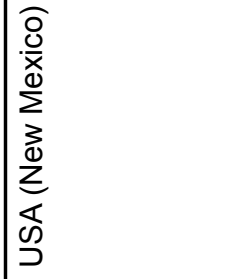 & 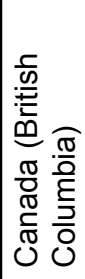 & \begin{tabular}{|l|} 
\\
\\
$\frac{\pi}{8}$ \\
$\frac{\pi}{0}$ \\
$\frac{\pi}{5}$ \\
0 \\
\end{tabular} & 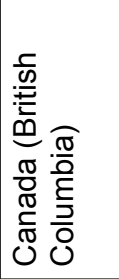 \\
\hline 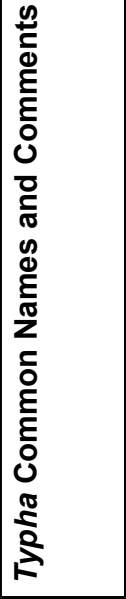 & 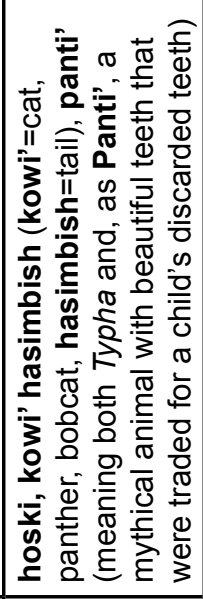 & 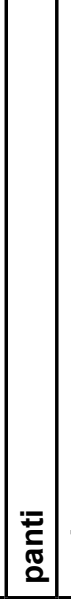 & $\begin{array}{l} \pm \\
\Phi\end{array}$ & 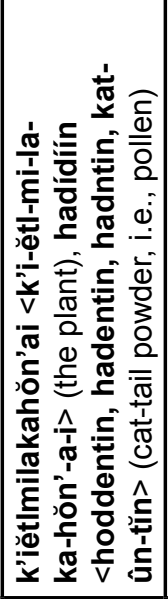 & 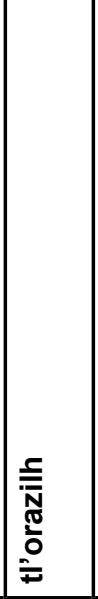 & 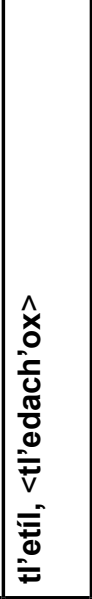 & 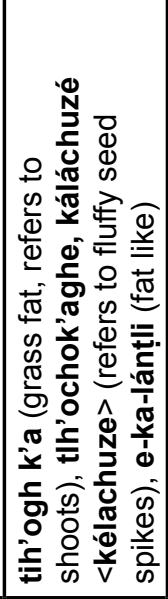 & 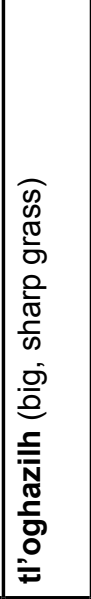 & 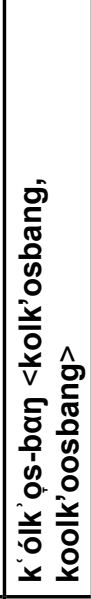 & 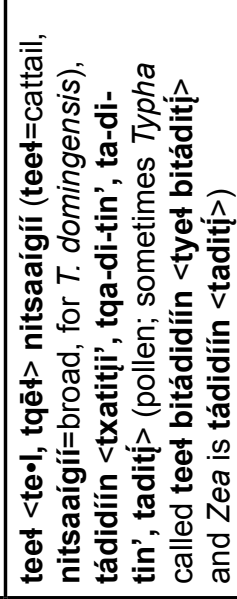 & $\begin{array}{l}10 \\
7 \\
0 \\
\frac{\pi}{0} \\
0\end{array}$ & 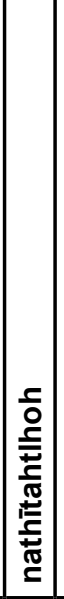 & 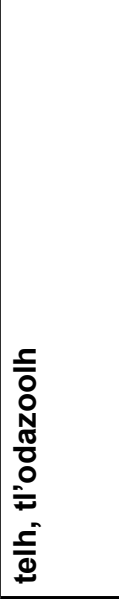 \\
\hline 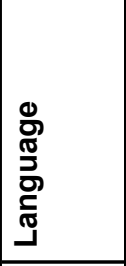 & 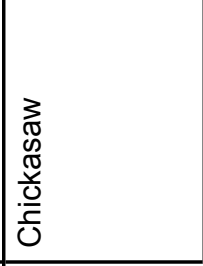 & 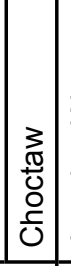 & 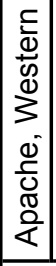 & 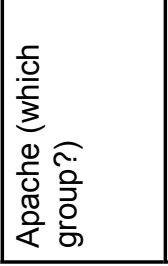 & 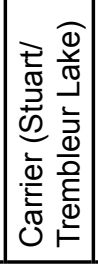 & 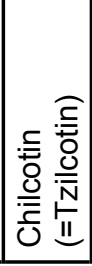 & 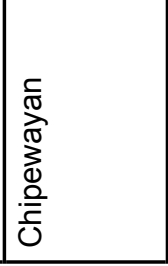 & 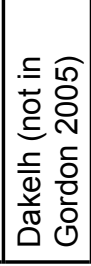 & 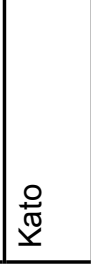 & $\begin{array}{l}\frac{0}{\pi} \\
\frac{\pi}{\pi} \\
\frac{\pi}{z}\end{array}$ & 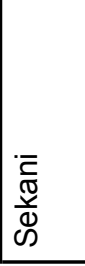 & 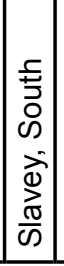 & 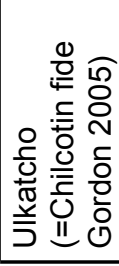 \\
\hline $\begin{array}{l}\stackrel{\lambda}{\bar{E}} \\
\frac{\sqrt{E}}{\pi} \\
\frac{\pi}{0} \\
\bar{J} \\
\omega\end{array}$ & 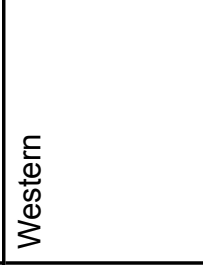 & & 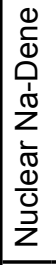 & & & & & & & & & & \\
\hline 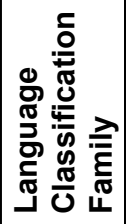 & 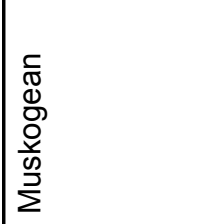 & & 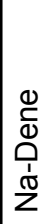 & & & & & & & & & & \\
\hline
\end{tabular}




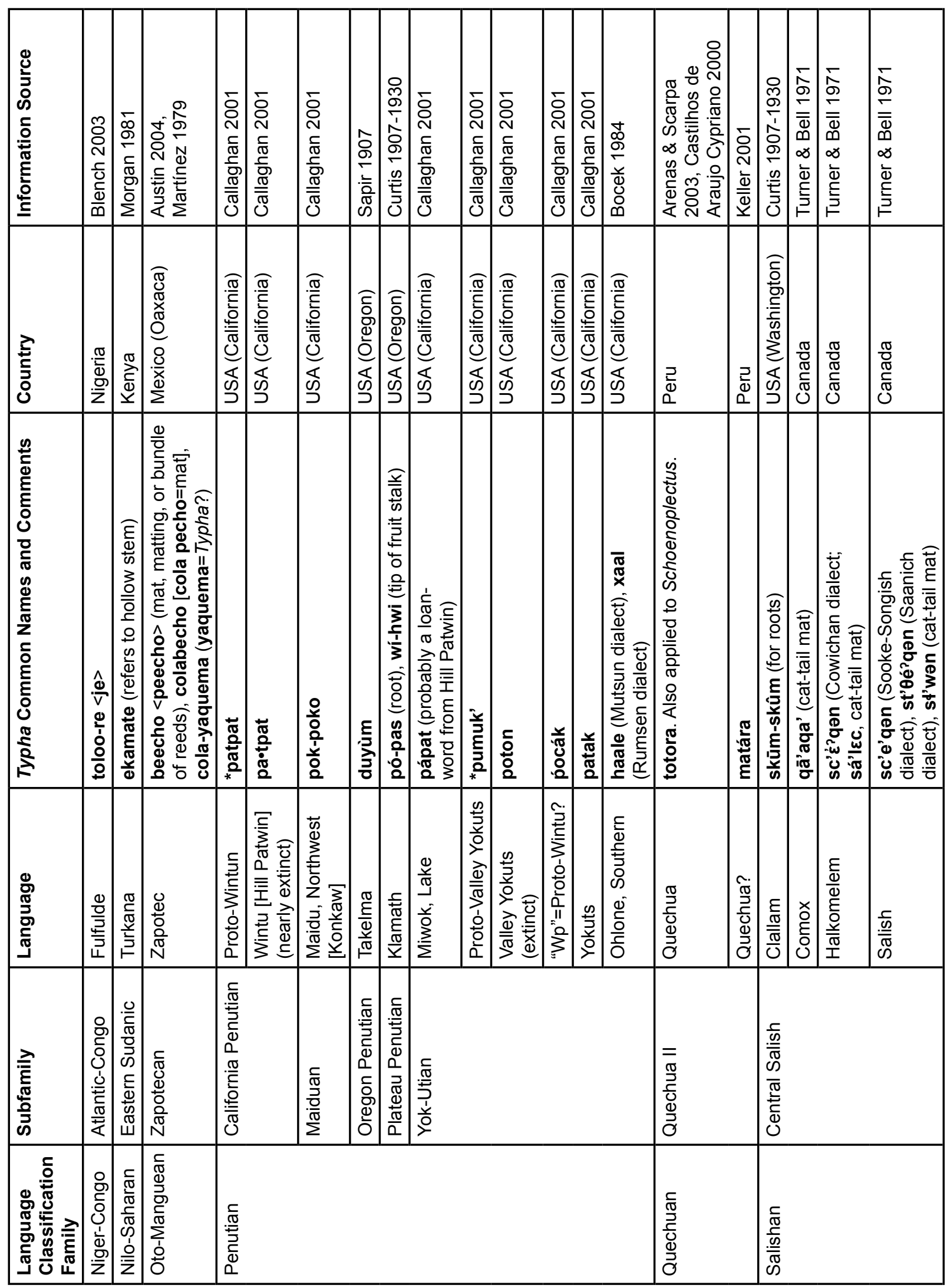


Austin - Sacred Connections with Cat-tail (Typha, Typhaceae) - Dragons, water-serpents and reed-maces

\begin{tabular}{|c|c|c|c|c|c|c|c|c|c|c|}
\hline 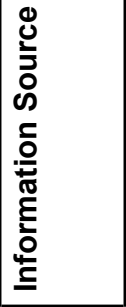 & 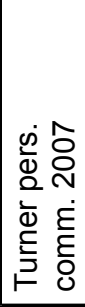 & 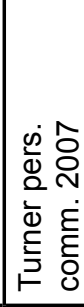 & 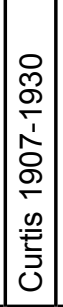 & 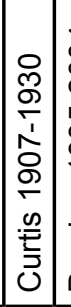 & 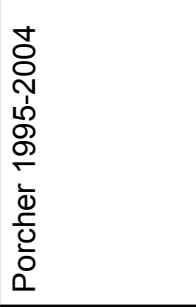 & 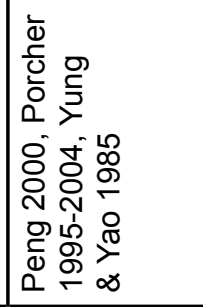 & 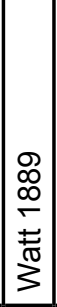 & 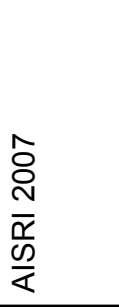 & 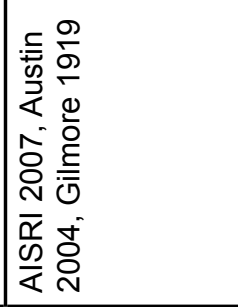 & 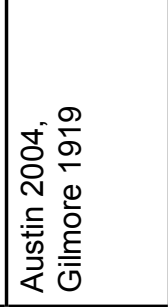 \\
\hline 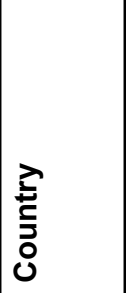 & 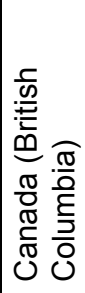 & 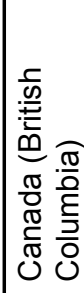 & 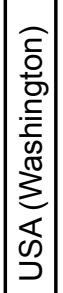 & 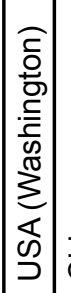 & 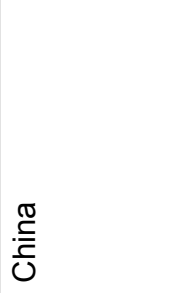 & 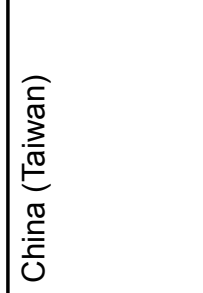 & $\begin{array}{l}\bar{\sigma} \\
\frac{\alpha}{0} \\
\frac{0}{2}\end{array}$ & 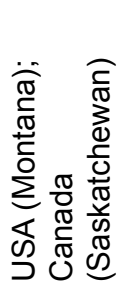 & 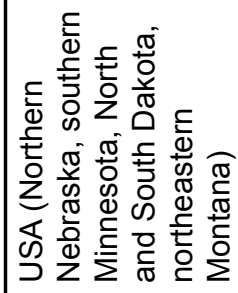 & 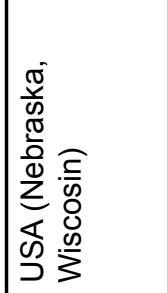 \\
\hline 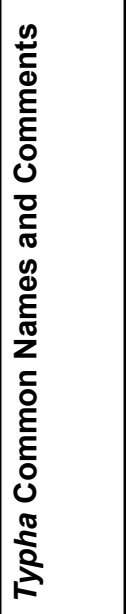 & 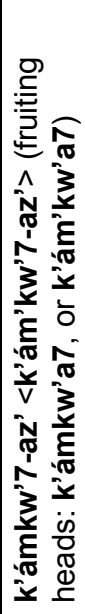 & 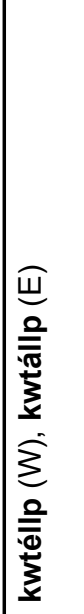 & 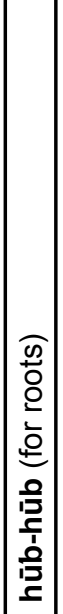 & 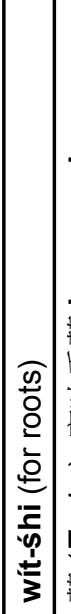 & 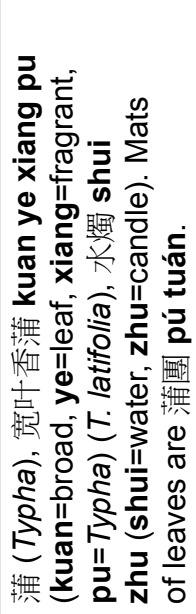 & 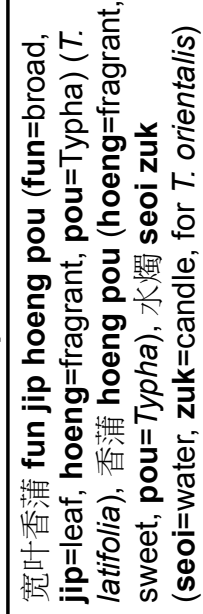 & $\begin{array}{l} \\
\frac{\pi}{2} \\
0\end{array}$ & 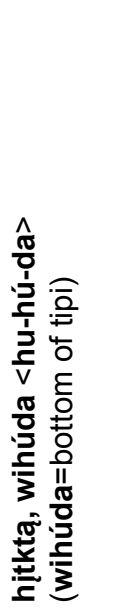 & 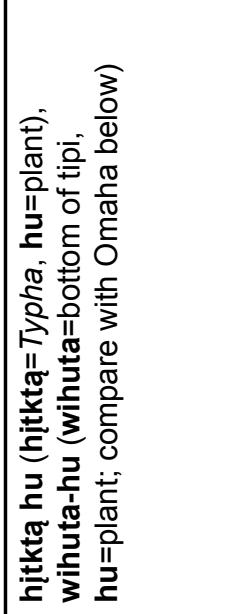 & 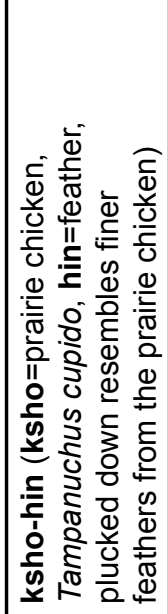 \\
\hline 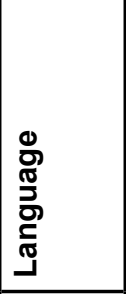 & 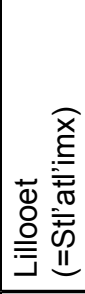 & 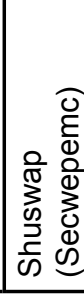 & 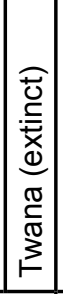 & 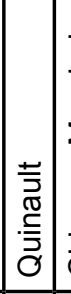 & 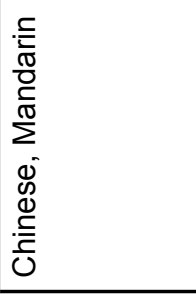 & 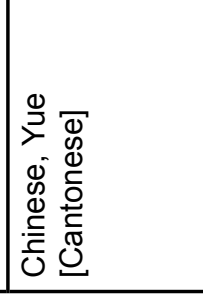 & 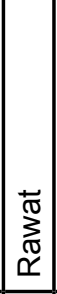 & 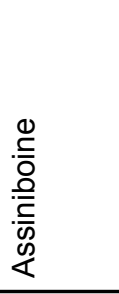 & \begin{tabular}{|l}
$\frac{\pi}{2}$ \\
$\frac{2}{0}$ \\
$\frac{2}{0}$ \\
0
\end{tabular} & 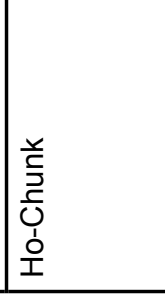 \\
\hline 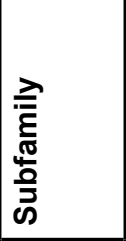 & 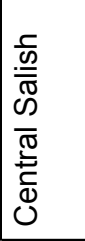 & & & 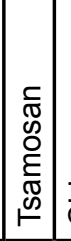 & 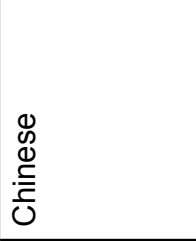 & & 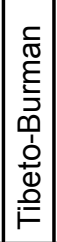 & 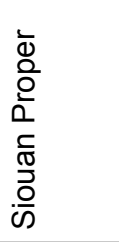 & & \\
\hline 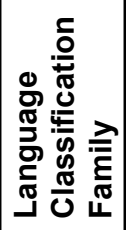 & 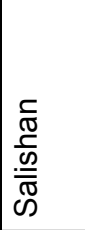 & & & & 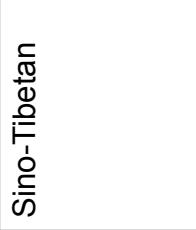 & & & $\begin{array}{l}\frac{\pi}{2} \\
\frac{0}{\omega}\end{array}$ & & \\
\hline
\end{tabular}




\begin{tabular}{|c|c|c|c|c|c|c|c|c|c|c|c|}
\hline 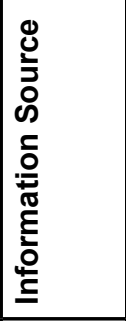 & 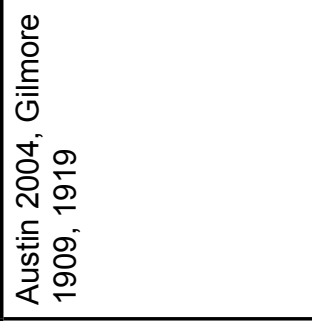 & 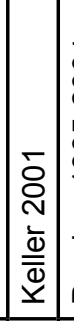 & 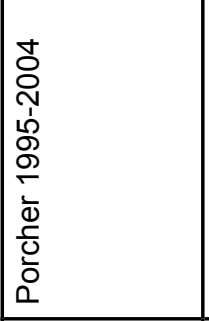 & 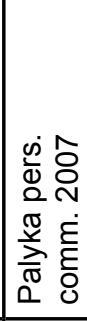 & 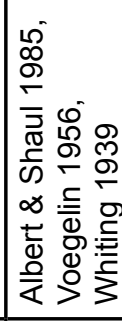 & 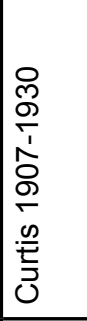 & 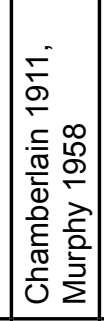 & 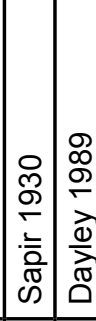 & 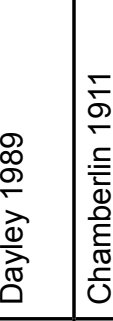 & 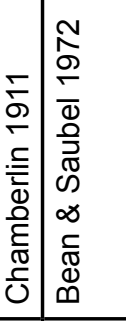 & 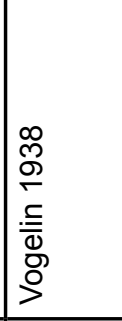 \\
\hline 童 & 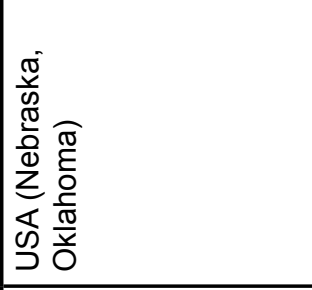 & 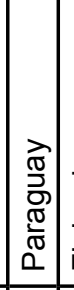 & 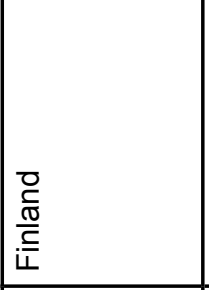 & 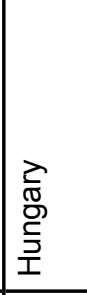 & 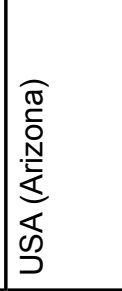 & 點 & 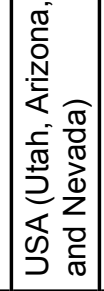 & 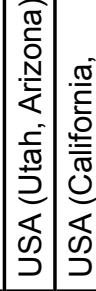 & 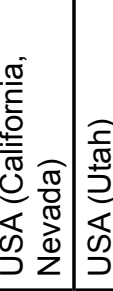 & 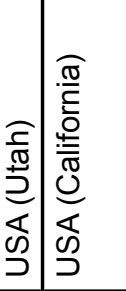 & 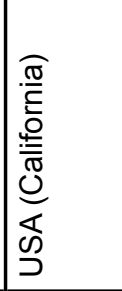 \\
\hline 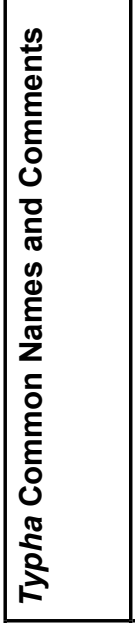 & 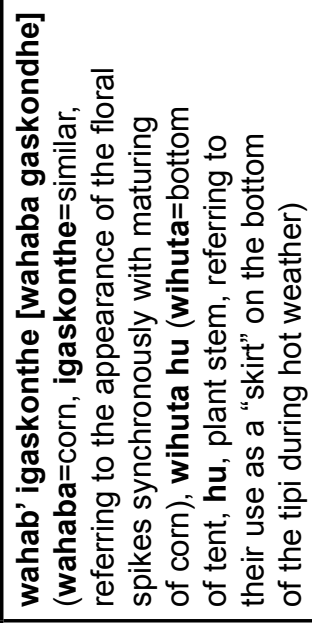 & 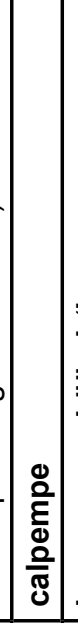 & 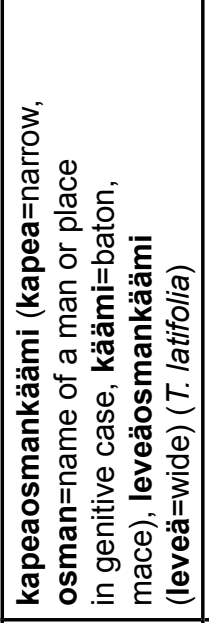 & 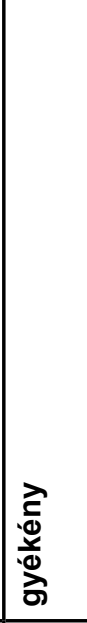 & \begin{tabular}{|l}
$\hat{0}$ \\
$\frac{0}{0}$ \\
$\frac{0}{3}$ \\
$v$ \\
0 \\
$\frac{0}{0}$ \\
$\frac{0}{3}$ \\
3 \\
\end{tabular} & 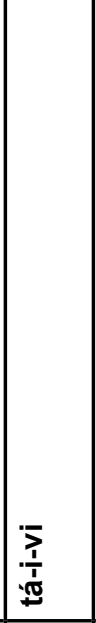 & 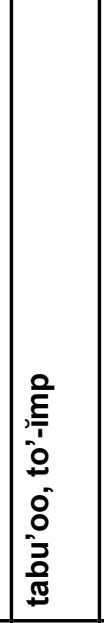 & 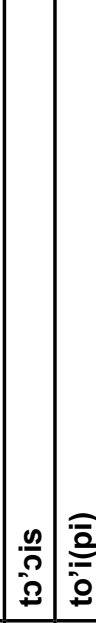 & 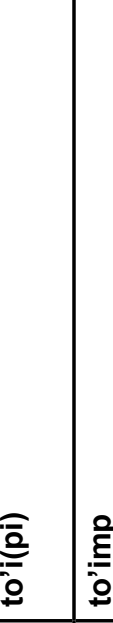 & 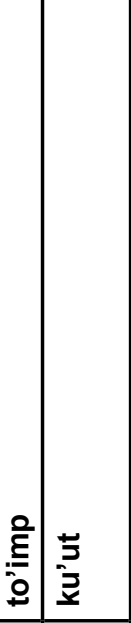 & 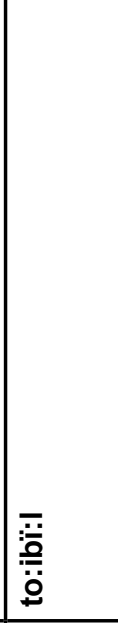 \\
\hline 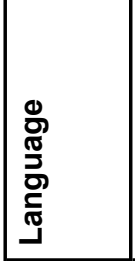 & 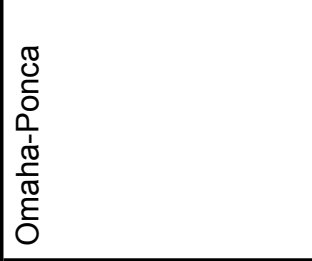 & 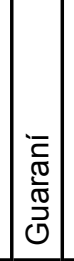 & 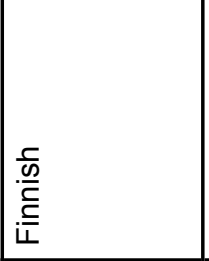 & 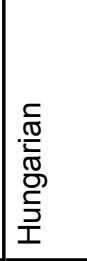 & 产 & 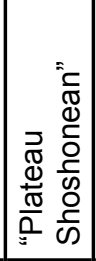 & 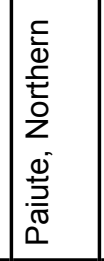 & 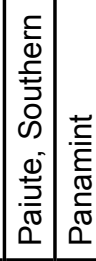 & 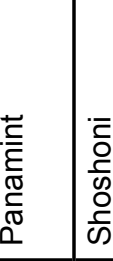 & 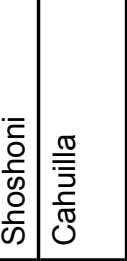 & 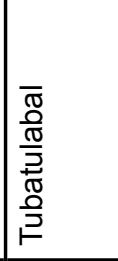 \\
\hline 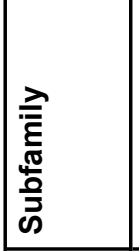 & 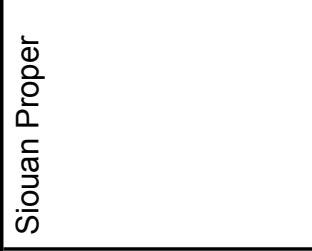 & 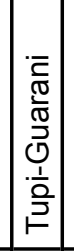 & 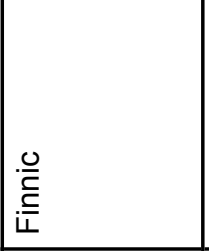 & 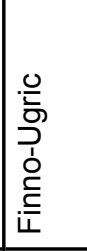 & 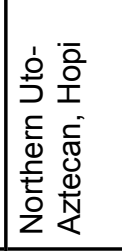 & 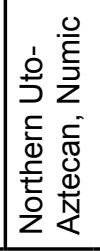 & & & & 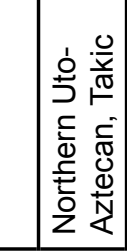 & 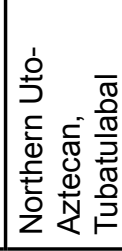 \\
\hline 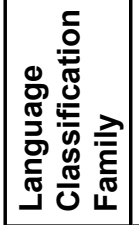 & 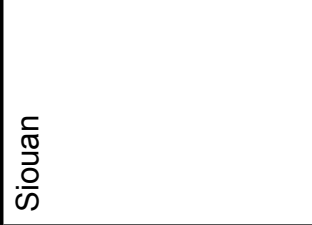 & $\mid \begin{array}{c}\bar{a} \\
\overline{2}\end{array}$ & $\frac{\overline{\frac{1}{5}}}{\frac{\pi}{5}}$ & כן & 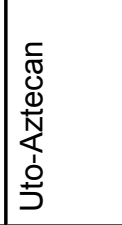 & & & & & & \\
\hline
\end{tabular}


Austin - Sacred Connections with Cat-tail (Typha, Typhaceae) - Dragons, water-serpents and reed-maces

\begin{tabular}{|c|c|c|c|c|c|c|c|c|c|}
\hline 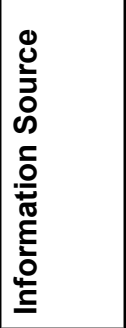 & 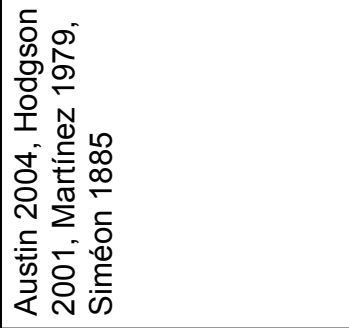 & 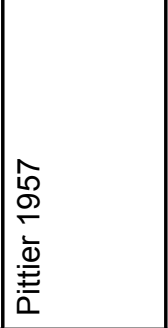 & 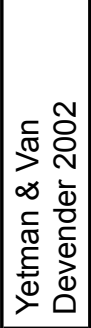 & 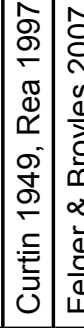 & 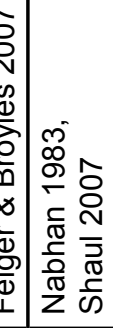 & 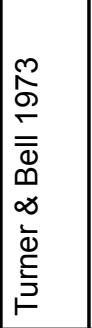 & 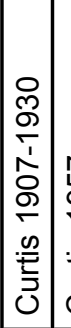 & 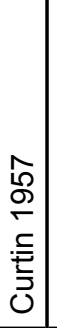 & 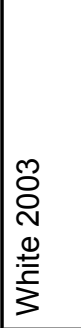 \\
\hline \begin{tabular}{l}
3 \\
\multirow{2}{3}{} \\
0 \\
0 \\
0
\end{tabular} & $\begin{array}{l}\frac{0}{x} \\
\stackrel{0}{x} \\
\end{array}$ & 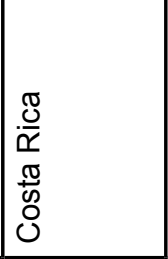 & 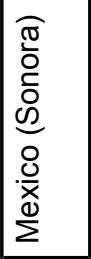 & 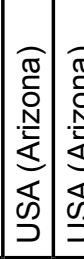 & 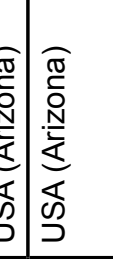 & 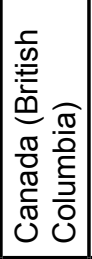 & 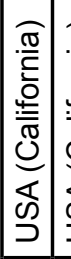 & 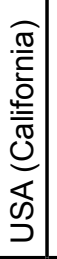 & 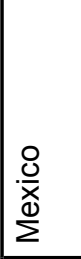 \\
\hline 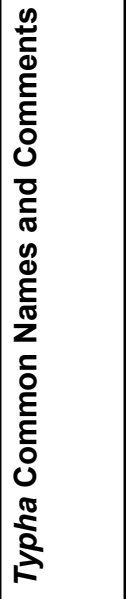 & 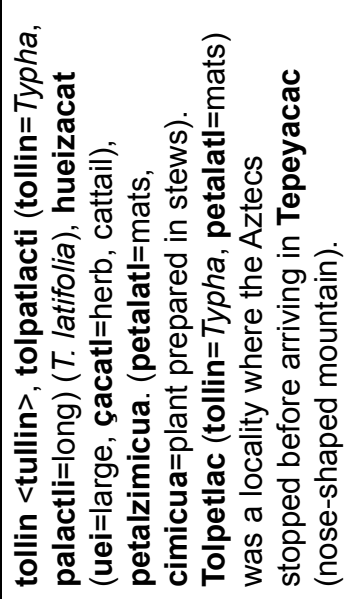 & 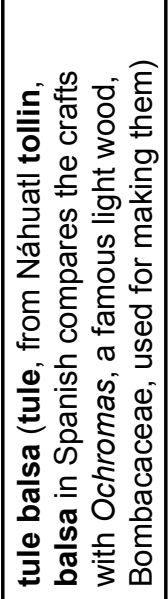 & 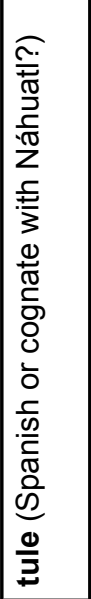 & 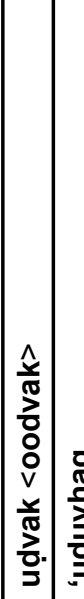 & 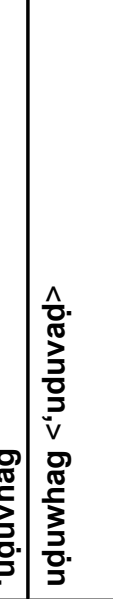 & 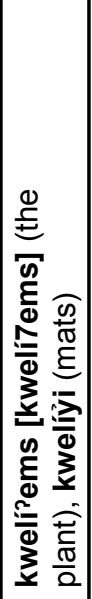 & 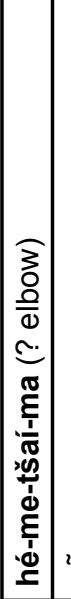 & . & 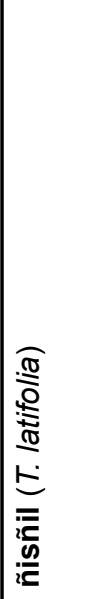 \\
\hline 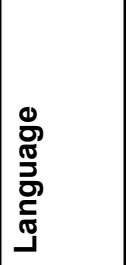 & 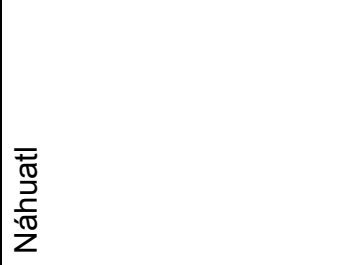 & 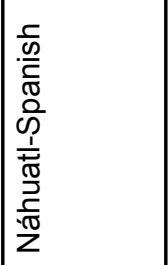 & 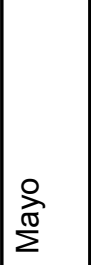 & 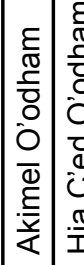 & 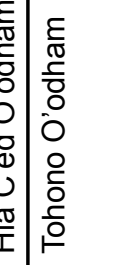 & 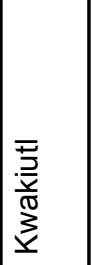 & 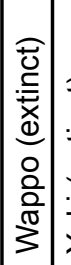 & 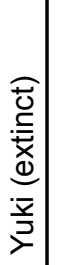 & 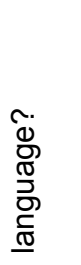 \\
\hline 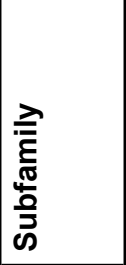 & 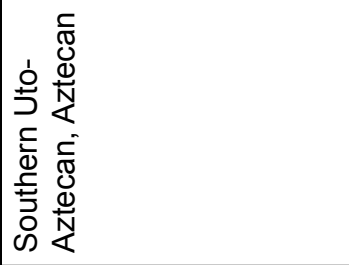 & & 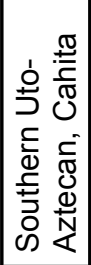 & 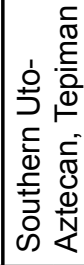 & & 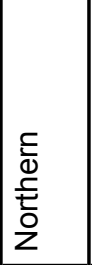 & 1 & & \\
\hline 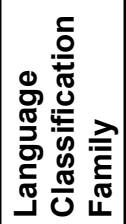 & 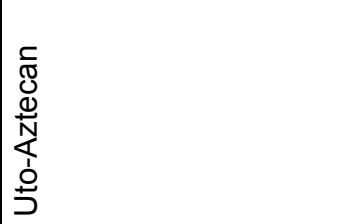 & & & & & 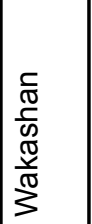 & $\frac{2}{2}$ & & 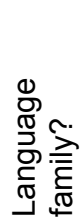 \\
\hline
\end{tabular}

